\title{
Insider-Outsider Representation and Social Democratic Labor Market Policy
}

\author{
Reto Bürgisser and Thomas Kurer
}

June 28, 2019

Accepted for publication in Socio-Economic Review

\begin{abstract}
Post-industrialization and occupational change considerably complicate partisan politics of the welfare state. This paper asks about the determinants of contemporary social democratic labor market policy. We argue that the composition of their support base is a critical constraint and empirically demonstrate that the actual size of different voter segments decisively affects policy outcomes under left government. We calculate the electoral relevance of two crucial subgroups of the social democratic coalition, labor market insiders and outsiders, in 19 countries and combine these indicators with original data capturing the specific content of labor market reforms. The analysis reveals considerable levels of responsiveness and demonstrates that electoral relevance is consistently related to policy outcomes. Social democratic governments with a stronger support base among the atypically employed push labor market reforms on their behalf - and vice versa. Our findings have important implications for our understanding of policy-making in post-industrial societies.
\end{abstract}

SER Keywords: labor market institutions; social policy; political parties; employment; comparative politics; political economy.

JEL Keywords: P16; J48; E24. 


\section{Introduction: Social Democratic Dilemmas}

The traditional view on the party politics of the welfare state held that left parties defend pro-welfare stances favoring their lower-class constituency and parties from the right aim to limit welfare spending in the interest of their better-off supporters. However, more contemporary perspectives emphasize that welfare politics have become more complex and more multifaceted in post-industrial societies (see Häusermann et al. 2013). One crucial factor adding complexity to the debate is the fact that the composition of political parties' support coalitions have undergone substantial transformation since the end of the industrial age. The literature agrees that the electorate of the social democratic party, the most important supporter of the welfare state in the traditional view, has been reshuffled particularly strongly (Rennwald and Evans, 2014, Gingrich and Häusermann, 2015, Evans and Tilley, 2017, Oesch and Rennwald, 2018). Clearly, a fundamentally altered support coalition calls for programmatic renewal and raises the question of which factors shape contemporary social democratic policy-making.

Programmatic re-orientation involves tough decisions since realigned voter segments provide parties with less clear, often heterogeneous and perhaps even conflicting signals with respect to their policy preferences. This is particularly true in the domain of welfare states and labor market policy, where social democratic parties face challenging trade-offs as a result of voter realignment. The programmatic dilemmas social democratic parties face in post-industrial societies have been described in different flavors but are always rooted in the vanishing of a homogeneous, unitary block of working class voters. Based on the evolution of post-Fordist societies and a two-dimensional policy space, Kitschelt (1994) described the trade-off between catering to the traditional blue-collar electorate and appealing to the growing white-collar constituency. In a similar vein, Gingrich and Häusermann (2015) showed that the Left has successfully substituted the decline in working class support with attracting votes among specific part of the educated middle class, leading to a "middle-class shift" in the welfare support coalition. Relying on a grouping of voters based on working conditions rather than class, Lindvall and Rueda (2014) emphasized the dilemma European social democratic parties are caught in due to the division of their traditional support coalition into insiders holding secure jobs and outsiders in atypical or precarious employment. 
Consequently, the question is no longer whether left parties represent their electorate but rather which part of their (potential) electorate they should side with. And this decision has crucial implications regarding the content and priorities of social democratic policy-making. The existing literature has not provided unequivocal answers to this question. In the light of the declining number of jobs in manufacturing, Kitschelt (1994) expects "electorally rational" social democratic parties to increasingly focus on white-collar constituencies. The dominating interpretation of the dualization literature, in contrast, is that social democratic parties will and do consider insiders their core constituency (Rueda, 2005, 2006). The "industrial blueprint" (Häusermann et al. 2016) of stable, protected full-time insider employment is often found exactly in those shrinking sectors Kitschelt identifies as less and less profitable to mobilize. Post-industrialization and occupational change thus considerably complicate partisan politics of the welfare state and electoral shifts demand re-thinking our assumptions of whose interests social democratic parties represent (Häusermann et al., 2013). Increasingly fragmented voter groups with distinct policy priorities provide ambivalent or even conflicting signals and parties have to balance and prioritize these demands.

We contend that the "electoral relevance" of distinct voter segments among a party's support coalition is an obvious but all-to-often neglected determinant of policy-making in the face of increasingly heterogeneous electorates. Based on the concept of dynamic representation (Stimson et al. 1995), we argue that social democratic labor market policy is directed by politically powerful subgroups among their diverse support coalition. "Rational anticipation", that is, the calculation of future electoral implications of dominating views among the electorate, affects policy priorities and hence shapes policy outcomes. Widespread private and public opinion polling allows for increasingly precise detection of such dominant attitudes.

We support our conjecture by explicitly studying the varying composition of social democratic voter coalitions across time and space. Following the influential dualization literature (Rueda, 2005: Emmenegger et al., 2012), we focus on labor market insiders and outsiders. We largely draw on the original, status-based classification as proposed by Rueda (2005) because we need clear-cut categorizations to calculate the relative size of the groups. ${ }^{1}$ We then apply Axelrod's (1972) concept of the "contribution to a coalition" to create empirical measures of insiders' and outsiders' relative political weight and assess their implication on 
actual labor market policy implementation under left government. To this end, we leverage large-scale individual-level data to operationalize those groups' contribution to the social democratic coalition as well as original, hand-coded data on labor market reforms to capture policy output. The empirical analysis demonstrates (a) considerable cross-national and temporal variance in the relative electoral weight of insiders and outsiders and, more importantly, (b) the explanatory power of relative electoral relevance when it comes to actual policy outcomes. The larger the share of atypically employed voters in the social democratic support coalition, the more favorable are the implemented labor market reforms to the demands of labor market outsiders, and vice versa.

Our results have important implications for political science research beyond the specific case of the insider/outsider divide and social democratic party strategies. We highlight the role of distinct voter segments' relative electoral relevance for parties aiming at dynamically representing decisive parts of their electorate, emphasizing that the underlying logic equally applies to any other situation where a party is confronted with competing demands from its core constituency. Importantly, such situations of increasingly heterogeneous electorates are a core characteristic of post-industrial societies and have become much more prevalent due to the erosion of traditional class voting (Oesch, 2006; Evans and Tilley, 2017, Oesch and Rennwald, 2018). We make a strong case for the argument that accounting for the relative political significance of different constituencies considerably adds to a more complete and encompassing understanding of policy-making in times of increasing electoral volatility.

\section{The Puzzle: Pro-Outsider Labor Market Reforms}

We focus on labor market insiders and outsiders because these groups are both considered part of the social democratic core electorate but have been shown to have conflicting interests when it comes to labor market policy (Burgoon and Dekker, 2010, Marx, 2014, Häusermann et al. 2015). The dominating interpretation of the literature is that social democratic parties will and do consider insiders their core constituency (Rueda, 2005, 2006), in particular when they face a high level of political constraints (Hübscher, 2017). The theoretical justification of social democrats' decision to side with insiders is substantially based on the crucial assumption of outsiders being disenchanted with politics. In Rueda's words, there 
is "the important fact that [...] outsiders tend to be less politically active and electorally relevant (as well as economically independent) than insiders" (2006, p. 388). Ten years later, the premise of politically alienated labor market outsiders appears to have become an unquestioned standard assumption in political economy. In an influential recent edited volume, labor market outsiders are plainly dismissed as "not a powerful electoral group in contemporary capitalist democracies" (Beramendi et al., 2015, p. 23).

As a consequence, one would expect social democratic parties to cater primarily or solely to their well-protected core voters and implement labor market policies that are distinctly in favor of insiders. However, a closer look at the more recent history of labor market reforms does not support this one-sided perspective. We have collected and hand-coded the policy content of the entire universe of labor market reforms enacted between 2000 and 2016 in Continental and Southern Europe. We describe the data in more detail below. For the moment, the reader only needs to know that the fine-grained coding allows to disentangle the distributional consequences of reforms in different domains of labor market policy for insiders and outsiders. Figure 1 shows a descriptive overview of enacted reforms in the fields of active labor market policy (ALMP) and employment protection legislation (EPL) (Figure SI2.2 provides a breakdown by country). Positive values on the Y-axis describe expansionary reforms, negative values indicate retrenchment. Various aspects of this Figure are noteworthy. First of all, there is no general trend of across-the-board retrenchment, despite the austerity pressure created by the Great Recession. Rather, governments have cut back social security in specific domains, primarily regarding employment protection (EPL) for both insiders and outsiders. Much in contrast, many governments enacted expansionary reforms in the field of active labor market policy over the course of the last two decades. This is largely in line with the existing literature describing the expansion of activation and social investment policies more broadly (Morel et al., 2012, Bonoli, 2013, Garritzmann et al. 2016). Even though the extent to which countries have implemented pro-outsider and social investment policies varies a lot (Hemerijck, 2015), the overall focus on ALMP at the cost of EPL provides clear evidence against pronounced pro-insider policies since it is mainly outsiders who demand and benefit from activation policies (Rueda, 2005).

This reading is reaffirmed by our reform data, which also coded the distributive implications of implemented reforms by differentiating between policies targeting insiders as 


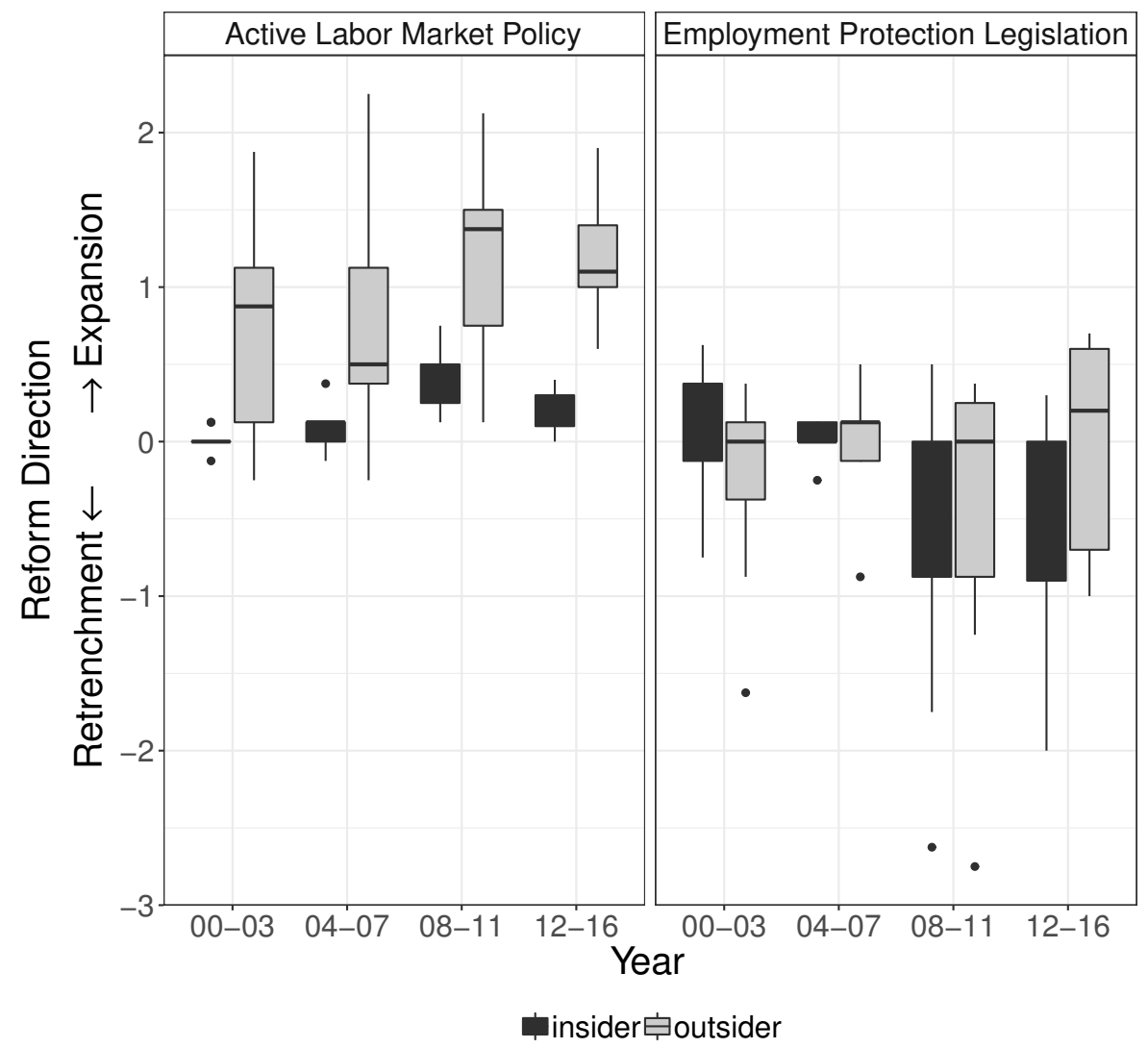

Figure 1: Effects of ALMP and EPL Reforms on Insiders and Outsiders, Continental and Southern Europe, 2000-2016.

Countries: Austria, Belgium, France, Germany, Greece, Italy, the Netherlands, Portugal, Spain.

opposed to policies targeting outsiders (in both directions, i.e. with respect to cut-backs as well as expansion). The strong focus of expansionary reforms on ALMP in conjunction with the fact that this kind of policy specifically aims at integrating and activating outsiders results in a surprisingly large share of policy reforms that mainly benefit labor market outsiders in vulnerable employment situations. On the other hand, standard employment protection for insiders has been increasingly deregulated, especially since the onset of the Great Recession. ${ }^{2}$

The considerable skew of labor market reforms in favor of outsiders in recent years is difficult to explain when neglecting how party constituencies have changed over time. From a vote-seeking perspective, a specific electorate is only worth rallying if it is sufficiently large and, in addition, likely to take part in politics. We argue that the existing literature has neglected and/or underestimated both the size of and the turnout rate among labor 
market outsiders, leading to a widespread but misleading image of an electorally irrelevant group. The first part of this paper thus aims to correct this allegedly commonsensical view on inert and insignificant outsiders. We demonstrate that the electoral relevance of labor market outsiders varies strongly across countries and regions. While in some countries the well-protected core of labor market insiders still accounts for the largest share of labor, in others, non-standard employment has in fact become the new standard. ${ }^{3}$ The rapid spread of atypical employment in many post-industrial democracies provides temporal variation in the relative size of labor market outsiders, which we exploit in a second step in order to assess the impact on labor market policy under left government. This differential development attributes varying electoral weight to the two groups, resulting in either an accentuated or weakened political dilemma for social democratic parties.

Our point of departure ties in with a burgeoning literature on the changing social democratic electorate in post-industrial societies (Best, 2011; Karreth et al., 2013, Gingrich and Häusermann, 2015, Abou-Chadi and Wagner, 2019). Gingrich and Häusermann (2015), for example, study the social democratic support coalition by distinguishing between different classes based on respondents' occupation and education level. This approach shares some obvious similarities with ours but also has some important differences. The main overlap concerns the fact that outsiders cluster in certain occupational groups. However, since this clustering is far from perfect ${ }^{4}$, our outsider category to some extent cross-cuts occupational groups. Whereas Gingrich and Häusermann (2015) focus exclusively on the differences between manual workers and the middle class, we expand the analysis by focusing on the entire group of workers. Most importantly, we thereby also include the significantly large group that Gingrich/Häusermann call routine workers ${ }^{5}$, which faces by far the highest prevalence of labor market vulnerability.

\section{Determinants of Social Democratic Labor Market Policy}

Political parties are important intermediary organizations that are expected to transmit preferences among the population - and particularly among their electorate - into policy outcomes. Broadly speaking, the vast literature on the determinants of political parties' position and/or issue emphasis ${ }^{6}$ can be divided into two camps. The first promotes a distinc- 
tive top-down perspective on policy making by emphasizing parties' strategic considerations to steer public debate towards issues they "own". Selectively highlighting their own policy issues turns elections into a contest on favorable home turf, which is generally expected to yield electoral gains (Petrocik, 1996; Bélanger and Meguid, 2008; Klüver, 2018).

The large literature dealing with representation and responsiveness, by contrast, posits quite a different view on the determinants of policy outcomes. In its most general formulation, the core idea behind "dynamic representation" is that vote-seeking parties need to follow the mood of the public in order to secure electoral gains (Stimson et al., 1995). In such a bottom-up process, parties are expected to take cues from voters and adjust their policy platform (e.g. Adams et al. 2004) or their issue emphasis (e.g. Klüver and Spoon, 2016) in a way that signals responsiveness and increases the chances of electoral support.

We do not attempt to settle this debate since the two perspectives are difficult to clearly disentangle due to obvious endogeneity concerns. Presumably, both apply to some extent (see Steenbergen et al., 2007). Parties certainly have strategic leeway in framing, issue emphasis and agenda setting. However, we contend that elite decisions on policy platforms do not occur in a vaccuum and political parties' room for maneuvre is thus most likely constrained by the distribution of preferences in the population. Consequently, we argue that parties' labor market policy positions are at least partly directed by the demands of politically powerful voter segments. "Rational anticipation" (Stimson et al., 1995), i.e. the calculation of future electoral implications of currently dominating views among the social democratic electorate, is expected to significantly impinge on social democratic parties' policy priorities and hence to shape policy outcomes under left government. While generally in line with traditional welfare state literature emphasizing bottom-up influence of powerful voter segments (Korpi 1983), our more contemporaneous take on social policy reforms acknowledges that welfare politics have turned from a positive-sum into a zero-sum game (Häusermann, 2010). Put differently, social democrats - and any other party, for that matter - have to prioritize some policy domains over others and cannot equally satisfy distinct (expansionary) demands from among their electorate.

The concept of rational anticipation explicitly posits an image of well-informed politicians/parties seeking re-election and thus strategically adjusting their political programs to 
the dominating voice in their - perhaps quite heterogeneous - support coalition. AbouChadi and Wagner $(2019)$ indeed show that mainstream left parties gain votes by taking up investment-oriented positions, which have become increasingly popular among the social democratic electorate (Gingrich and Häusermann, 2015). In a similar vein, we would expect social democratic parties to adjust their policy priorities to the balance of power within their core electorate. Instead of focusing on party manifestos, as most of the existing literature, we aim to go one step further and look at a more consequential outcome. We study the relationship between the composition of the electorate and actually implemented policy reforms once parties win elections and form the government.

More specifically, we hypothesize that the country-specific electoral relevance of labor market outsiders relative to insiders affects the kind of labor market reforms social democratic parties implement when in government. Our argument has four observable implications. (1) Mere group size of different subgroups of the population per se should not affect policy outcomes since electoral relevance also depends on participation rates and vote choice. (2) The electoral relevance of insiders and outsiders should not generally affect policy outcomes. Both groups are considered part of the left core electorate and non-left governments' policy decisions should not be affected by their relative political clout. (3) In contrast, the relative electoral relevance of outsiders vis-a-vis insiders should impact on labor market reforms under governments with a significantly large share of left seats. In this case, we expect spending for ALMP and PLMP as well as the frequency of pro-outsider reforms to increase with outsiders' contribution to the coalition. ${ }^{7}$ More technically speaking, the focus of the empirical analysis is on the interaction effect between outsiders' electoral relevance and left government on implemented labor market reforms. (4) By implication, in countries with electorally dominant insiders, left government should, if anything, be negatively correlated with spending on and frequency of outsider-friendly labor market reforms.

\section{The Changing Electoral Relevance of Insiders and Outsiders}

In our assessment of electoral relevance, we build on Axelrod's (1972) approach to study what he called the "contribution to a coalition". ${ }^{8}$ The three parameters needed to estimate the contribution of a group to a party's total vote share are size, turnout and party choice 
("loyalty" in Axelrod's terminology). In the following, we briefly discuss how the relative electoral relevance of outsiders as opposed to outsiders has evolved over the course of the past two or three decades.

An obvious starting point for studying the electoral relevance of different constituencies is relative group size. Focusing on insiders and outsiders, occupational change in recent decades has led to remarkable changes in this regard. Until the 1970s, the model of full-time wage employment dominated the world of work. The bigger part of workers consisted of archetypical insiders, most of them employed in the second sector. This pattern steadily changed in the course of continuous deindustrialization and the concomitant growth of the service-sector. The rise of novel forms of atypical employment, most importantly temporary and (involuntary) part-time work, has become a central issue in all advanced post-industrial democracies (De Grip et al., 1997). Figure 2 displays the remarkable spread of atypical employment in Europe since the 1980s. While unemployment seems to be dominated by cyclical trends, temporary employment has constantly been on the rise since the early 1980s. The most recent economic crisis has further reinforced the spread of labor market vulnerability as the hardest hit sectors have, again, been those dominated by insiders: manufacturing and construction (Autor, 2010).

Critical mass is a necessary but not a sufficient condition for achieving electoral relevance. Based on the assumption of low political activity, Rueda maintained that social democrats will cater to insiders even if outsiders are "numerous" (2005, p. 86). Therefore, the second important aspect of electoral relevance is turnout. If policy makers assume every second individual of a specific subgroup of society to go to the ballot, the electoral relevance of this subgroup is only half of what it could be. What do we know about turnout among outsiders? Although existing research provides some evidence for lower political activity (Häusermann and Schwander, 2012, Rovny and Rovny, 2017), the actual magnitude of the participation gap between insiders and outsiders deserves some more attention. As labor market risks have "spread well into the more highly educated segments of the population" (Häusermann et al. 2015, p. 235; see also Table SI2.1 , the rise of outsiderness goes hand in hand with a steady shift in its composition. Contemporary labor market vulnerability is by no means restricted to the poor and low skilled, the usual suspects of non-voting (Leighley and Nagler, 2013), but increasingly affects individuals with all the necessary means to political participation. 


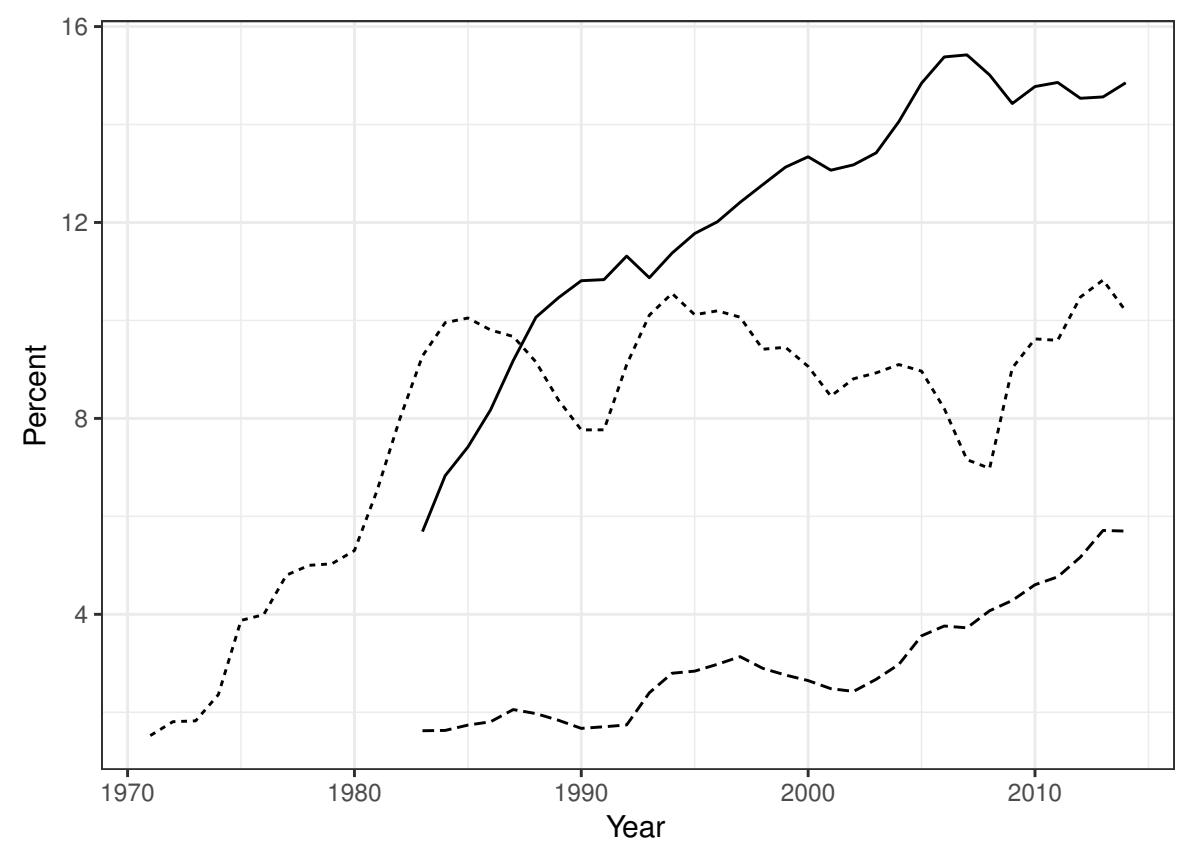

— Temporary Work -... Unemployment --- Invol. Parttime

Figure 2: Share of atypical employment in Europe, in \% of working-age population (Source: OECD Employment Database; data weighted by population).

The remaining crucial aspect in a discussion about the electoral relevance of a specific group is party choice. Traditional insider/outsider theory has been more than clear on the prime example of a social democratic voter: the well-protected insider. However, we suspect that support for the Left among insiders is overestimated, whereas it is underestimated in the case of outsiders, resulting in a much less clear-cut picture. First, we argue that social democratic parties are a likely choice for outsiders. On election day, voters have to choose from existing "policy packages" (Emmenegger, 2009) and need to compromise. The existing literature has heavily focused on employment protection to justify the expectation of strong support for social democrats among insiders but weak or even inexistent support among outsiders. However, the overall package offered by social democrats might still be one of the more interesting options for the latter. Indeed, Picot and Menéndez (2017) show that policies to mitigate the adverse effects of non-standard employment are clearly the domain of left parties and Schwander (2018), more specifically, shows that social democrats do address outsiders' concerns to a significant extent in electoral campaigns. Outsiders thus might support social democratic parties despite their adherence to employment protection 
since an ideal policy package that matches preferences in each and every policy domain is hardly available. Parties with a more skeptical stance on employment protection are likely to combine this position with a generally critical attitude towards welfare provision. And general social policy retrenchment cannot be in the interest of outsiders, which makes the major right an unlikely choice (Rovny and Rovny, 2017).

Second, we question the assumption of unambiguous support for the Left among insiders. The realignment literature has pointed out that the working class vote has experienced a rightward shift (Gingrich and Häusermann, 2015). Right-wing populists have been shown to successfully mobilize among moderately skilled private sector insiders (Bornschier, 2010) and especially attract support from small business owners and production workers (Oesch, 2008). It is therefore not primarily precariousness or low wages that drives workers into the arms of right-wing populist parties but rather the fear of losing status and/or privileges that were previously deemed protected (Gidron and Hall, 2017, Kurer, 2017). As insiders are much more likely to depend on such "taken-for-granted features" (Rydgren, 2013, p. 6) than the more vulnerable outsiders, they seem especially prone to abandon the left and instead vote for its populist competitor from the right. All in all, then, insiders might not be so much more likely to support social democratic parties than vulnerable outsiders who demand social policy protection as a reaction to economic insecurity (Burgoon and Dekker, 2010, Rehm, 2009, Häusermann et al. 2015.

Taken together, this section discussed several reasons why the electoral relevance of outsiders relative to insiders might have been underestimated in previous accounts. In that case, according to our electoral relevance argument, the surprisingly high share of prooutsider policy in recent years is not puzzling but a logical consequence of social democratic parties anticipating changes in their electorate and aiming at dynamically representing their pivotal voter. 


\section{Measurement, Data and Method}

In accordance with our theoretical explanations, we build on the following formula originally proposed by Axelrod (1972) to empirically examine the relative electoral relevance of insiders and outsiders for Social Democratic parties:

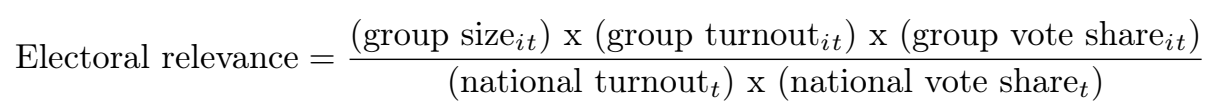

The formula specifies how the three parameters size, turnout and vote share are combined to assess the total contribution of a given group $i$ at time $t$. "Group vote share" is the estimated average probability of the group under consideration to vote for the specified party. Most importantly for our purposes, it also provides a straightforward handle to empirically compare the electoral relevance of one group $i$ at time $t$, e.g. insiders, to that of another, e.g. outsiders.

To be sure, not all of the constituent parameters of the above formula are entirely exogenous to the specific supply-side context or electoral rules. Axelrod $(1972)$ himself discussed some "strategic considerations" for parties in the light of his conceptualization. While group size is difficult to manipulate, turnout and vote choice are to some extent "elastic" to parties' appeals. Whether citizens turn out to vote depends not only on socio-economic background but also on electoral rules and the party system (Blais and Dobrzynska, 1998). While both aspects certainly affect our estimates of relative electoral relevance to some extent, we do not expect systematic biases since we are primarily interested in the difference between two groups within the same socio-economic class in the same country. Issues of endogeneity are more obvious with respect to the propensity to vote for Social Democrats. Elite-mass linkages are known to be of a reciprocal nature (Steenbergen et al., 2007), meaning that it is not only the electoral relevance of a group that affects parties' policy stances but also, simultaneously, the other way round. The particular policy proposals put forward will to some extent affect the inclination of specific subgroups of the electorate, e.g. insiders or outsiders, to vote for the party. 
In terms of conceptualization, we largely rely on the original definition of outsiders as proposed by Rueda (2005), but coded students as outsiders only if they indeed faced some form of atypical employment. The group of outsiders consists of part-time workers (less than 30 hours), temporary workers and the unemployed. Insiders are workers with a full-time permanent working contract. The residual group consists of what Rueda calls "upscales", i.e. higher skilled professionals, large employers and business owners as well as self-employed citizens who are not considered part of the social democratic core electorate. More recently, the insider-outsider literature has been enriched by alternative and more fine-grained ways to operationalize outsiderness, e.g. risk-based, continuous measures of labor market vulnerability (Rehm, 2009, Schwander and Häusermann, 2013) or longitudinal approaches to labor market disadvantage that take into account previous experience and scar effects (Emmenegger et al. 2015). ${ }^{9}$ We deliberately stick to the simple initial version because the calculation of relative group size requires a clear-cut distinction between insiders and outsiders, which is less straightforward when using continuous measures. Furthermore, a status-based operationalization will yield more conservative estimates of the prevalence of outsiderness and thus prevent us from overestimating the share of outsiders based on risk-based classifications. We test our conjectures on a sample consisting of 19 European countries that are considered advanced capitalist democracies. ${ }^{10}$

In order to calculate the electoral relevance of insiders and outsiders, we need three parameters: group size, turnout, and vote share. For the first parameter, group size, we rely on the large samples of EU-SILC data (2004-2015) in order to provide reliable estimates of relative shares of both insiders and outsiders among the entire labor force. The political parameters are derived from the European Social Survey rounds 1-8 (2002-2016, see SI2.2). We run two separate unconditional logistic regression models to calculate predicted probabilities of the effect of labor market status on turnout and vote choice, respectively. ${ }^{11}$ Unconditional (i.e. models without control variables) because we want to capture the effect of inherent "outsiderness" instead of partial correlations under the control of covariates such as age, gender or occupation. When thinking about electoral relevance of different groups, it is this unconditional effect of outsiderness that should matter most for party strategies. Having said that, controlling for compositional effects and thus examining partial correlations of 
outsiderness - unsurprisingly - decreases the participation gap and further strengthens our central claim (see Table SI2.3 in the appendix).

In the second empirical part, we test our hypotheses regarding the bottom-up impact of insiders/outsiders on different policy outcomes with a pooled times-series cross-section (TSCS) analysis. For this, we have created a dataset that includes measures of labor market reforms effects on insiders and outsiders, spending on active and passive labor market policy, strength of social democratic governments, electoral relevance of insiders and outsiders, as well as control variables. We use four different measures to assess policy outcomes.

The first two output variables are based on our original, hand-coded database that contains information on the policy content of all enacted labor market reforms in Continental and Southern Europe between 2000 and 2016. In a first step, information on all the policy changes in the fields of employment protection legislation (EPL), passive and active labor market policy (PLMP, ALMP), early retirement (ER) and short-time work (STW) were collected. In total, the dataset includes 1'045 policy changes. Table SI1.1 in the Appendix shows the detailed distribution by country and policy instrument. The focus of the coding is on the extent to which certain policy changes insulate insiders and/or outsiders from particular labor market risks. ${ }^{12}$ Based on the detailed explanation of the policy content and, if available, evaluation reports and secondary literature on specific labor market reforms, each policy change has been assigned a value of +1 if it improves the situation of outsiders/insiders, 0 if the policy change does not affect outsiders/insiders, and - 1 if worsens the situation of outsiders/insiders. In addition, each policy change is weighted by 1 if it is a comprehensive reform that addresses the broader design of existing systems or by 0.5 if it is only a marginal change. In a final step, all the reforms in one country-year are aggregated together and measure the sum effect all the policy changes have on insiders and outsiders in a given country-year. Data collection and coding has proceeded in several steps to ensure that all relevant labor market reforms were found and hand-coded correctly (see Appendix for a more detailed description on data collection and coding). In stark contrast to spending data, such a reform measure can more clearly distinguish reform effects on insiders and outsiders and it minimizes potential confounding factors. In addition, it allows to link policy output more directly to the party in office, whereas it is more difficult to attribute certain 
spending outcomes to specific government decisions as reforms only become visible some years later.

The drawback of our detailed coding is that the reform measure is only available for nine countries (Austria, Belgium, France, Germany, Greece, Italy, the Netherlands, Portugal, and Spain). As a reaction, we complement our empirical evaluation with traditional spending data, despite the discussed concerns, in order to test the robustness of our results and broaden the geographical scope of the analysis. These measures are straightforward: we use spending on active labor market policy and spending on passive labor market policy as indicators for pro-outsider policies. The data comes from the Comparative Political Dataset (Armingeon et al., 2018). We try to minimize the main concern with spending data, i.e. their interlinkage to various other factors (Clasen and Siegel, 2007), by controlling for the most obvious confounders such as the unemployment rate and real GDP growth.

Following our theoretical argument, we are mainly interested in two explanatory variables and their interaction: the electoral relevance of insiders/outsiders and the strength of social democratic governments. For the former we use our measure of electoral relevance that we have developed above ${ }^{13}$ and the latter we measure by cabinet posts hold by the main social democratic party in percentage of total cabinet posts (weighted by the number of days in office in a given year). We adjusted the left government variable from the CPDS I dataset (Armingeon et al. 2018) so that cabinet posts hold by other left parties are excluded. We include further control variables for the unemployment rate, real GDP growth and union density (data from Armingeon et al. 2018), all lagged by one year.

In order to test our core hypothesis, we include an interaction term between the two main explanatory variables - the strength of social democratic parties and the electoral relevance of insiders/outsiders. It has been pointed out recently that most current research assumes a linear interaction effect when it is in fact non-linear and that estimates often lack common support of the moderator, i.e. excessive extrapolation (Hainmueller et al. 2018). We therefore follow the three recommendations by Hainmueller et al. (2018): First, we use a binning estimator that breaks the continuous moderator $(Z)$ into three bins (dummy variables) and interact these with the other explanatory variable (X). Second, we use a kernel estimator that allows to flexibly estimate the functional form of the marginal effect of $\mathrm{Z}$ on 
$\mathrm{Y}$ across values of $\mathrm{X}$. Third, we always plot the interaction effects together with a histogram showing the distribution of the moderator variable in order to prevent severe extrapolation. The diagnostics indeed demonstrate that the interaction terms are linear (see Figure SI2.4 in the Appendix).

The use of TSCS data violates several assumptions of ordinary least squares (OLS) regression. To take the problems of autocorrelation and heteroskedasticity into account, we estimate all the models with a lagged dependent variable (LDV) and country-clustered standard errors (Beck and Katz, 1995). Prais-Winsten (AR1) regression, instead of LDV, results in very similar findings. We also include country-fixed effects to account for unit heterogeneity and unobserved country-specific factors that do not vary over time $\overline{B e c k}$ 2001).

\section{Descriptives}

\section{The Electoral Relevance of Insiders and Outsiders}

We apply Axelrod's formula to calculate the relative electoral relevance of insiders and outsiders for social democratic parties in 19 European countries for the years 2002 to 2016 . To reiterate, the first parameter, group size and the resulting relative group share, is derived from EU-SILC. The additional parameters, turnout and support for social democratic parties among both groups as well as the reference group, the national average, are estimated in the ESS. We show the very rich but slightly overwhelming full descriptive data for all parameters in each country in Table A1 in the appendix. Figure 3 provides a more compact overview about the relative weight of distinct subsets of voters in the social democratic support coalition by plotting the ratio between the electoral relevance of insiders vis-a-vis outsiders. The horizontal line at the ratio $=1$ indicates perfect balance between insiders and outsiders in terms of electoral relevance for social democratic parties. To give a reading example, in Ireland, insiders' contribution to the social democratic coalition (averaged over the time span between 2002 and 2016) is an estimated $27.5 \%$ whereas outsiders' contribution amounts 


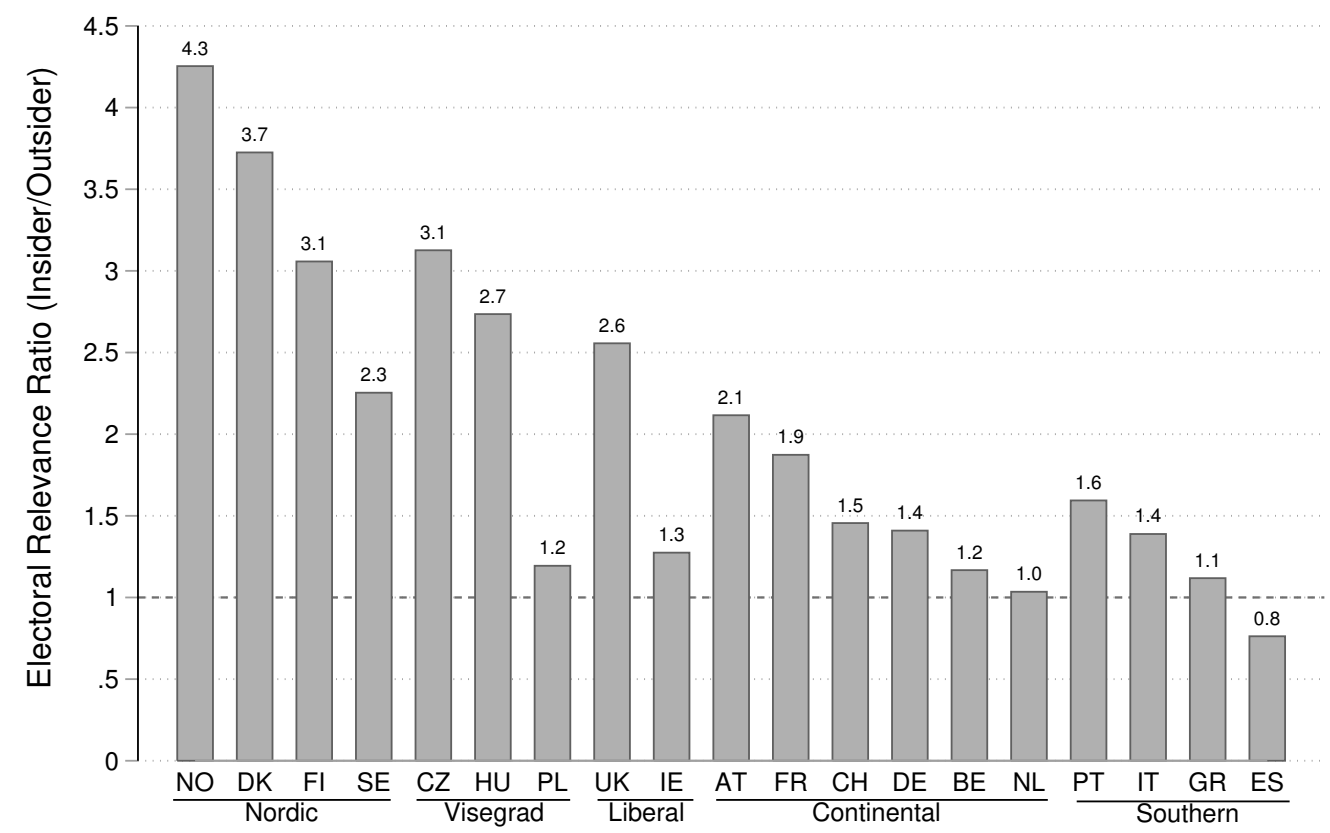

Figure 3: Electoral relevance ratio by country, average values 2002-2016

to $21.0 \%$. This results in a slight predominance of insiders among the potential Irish social democratic electorate $(27.5 / 21.0=1.3)$.

This first descriptive evidence yields two important insights. First, insiders are (still) electorally more relevant than outsiders. However, in many places, particularly in Continental and Southern Europe, the gap is small and perhaps not sufficient to explain social democratic strategies abandoning the demands of outsiders. Second, the remarkable crosssectional, but also within-regime, variance highlights the different significance of the social democratic dilemma across Europe. In countries like Spain, Greece but also the Netherlands, Belgium, Ireland or Poland outsiders represent a large part of the electorate, comparable in size to labor market insiders. In an extreme case like Spain, outsiders in fact outnumber insiders in terms of electoral relevance.

Consequently, in these countries, social democrats truly do face a dilemma as they are confronted with two similarly important groups of potential supporters with clearly distinct policy preferences. In contrast, the strategic considerations for social democrats in most Scandinavian countries, Hungary or the Czech Republic are much less complex. As the working class is still dominated by standard employment, resulting in electoral relevance 
ratios of 3 and above, insider-friendly policies seem to be a straightforward and reasonable programmatic choice for vote-seeking social democratic parties.

Taking electoral relevance into account helps to put the balancing act of social democratic parties into perspective. Promoting policies that benefit insiders might lead outsiders to abandon the center-left. However, as long as one group dominates the electorate, policy choices for vote-seeking parties are not very delicate, thus strongly mitigating the social democratic dilemma. For example, in the Swedish case discussed by Lindvall and Rueda (2014), an emphasis on insider policies makes sense since insiders have more than twice the weight of outsiders (ratio $=2.3$ ) in the electorate of the Swedish Social Democratic party. In contrast, as demonstrated by Lindvall and Rueda's analysis, pro-outsider reforms are electorally costly. Strategic decisions are even more straightforward in other Nordic countries, where the ratio in favor of insiders is even higher. The relative electoral relevance of insiders and outsiders thus offers the party elite a dominant strategy.

Finally, one aspect we have not addressed so far concerns the absolute electoral decline of the social democratic vote share across Europe. To be clear, we are primarily interested in the relative strength and, thus, policy influence of different social democratic constituencies rather than their combined electoral relevance vis-a-vis other parties. However, we do not want to ignore the fact that many of the analyzed social democratic parties have lost a significant share of voters to competing parties in recent years. While it is clearly beyond this article to provide an answer to the important question of vote switching, which requires longitudinal data to be properly addressed, our data on the relative electoral relevance of different sub-constituencies allows for some tentative insights. In Figure SI2.1 in the appendix, we show how the social democratic voting propensity of the two groups, insiders and outsiders, changes over time compared to social democrats' national vote share. Since we look at a relatively short period of time, in most countries we do not see spectacular changes. Still, as expected, a steady downward trend is visible in many countries. Exceptions are more dramatic cases like Poland and Hungary, where social democratic parties have been almost electorally obliterated (mainly) due to corruption scandals that accelerated the decline, visible in almost any other country. Our data does not reveal a consistent pattern as to whether insiders are more likely than outsiders to leave social democrats. 


\section{Results}

The presentation of results is split into two sections with distinct measures of the dependent variable (labor market policy intervention). The first part is based on our novel reform database with original, hand-coded data for nine Continental and Southern European countries, which we consider the "gold standard" in terms of measuring policy output. The very fine-grained coding of reforms comes at the cost of a limited sample of countries, however. In a second step, we thus recede to more traditional spending measures in order to validate our original dependent variables and to test our hypotheses with models based on a geographically more encompassing sample with more statistical power.

\section{Electoral Relevance and Labor Market Reform Output}

How does the relative electoral relevance of insiders and outsiders affect actual social democratic policy making, i.e. labor market policy output under social democratic government? Table 1 presents the results from our models looking at actual reform output. The coding captures how outsiders (M1-M3) and insiders (M4-M6) have been affected by implemented labor market reforms. As hypothesized, Model 1 and Model 4 confirm that neither the group size of insiders nor outsiders has a direct effect on the two dependent variables. Thus, there is no direct correlation between a change in the group size of specific subgroups of the electorate and labor market reforms. The absence of such a functional relationship between mere group size and policy outputs lends support to our operationalization of electoral relevance that takes political mobilization into account by also including participation rates and vote choice. Similarly, the results in Model 2 and Model 5 show that neither the strength of social democratic governments nor the electoral relevance of insiders or outsiders has a direct effect on the two reform measures. Again, this is an expected result given our theoretical reasoning. Social democratic parties are expected to implement pro-outsider (insider) policies especially or even only if outsiders (insiders) form a substantial part of their electorate. Since this is not the case across the board (see Figure 3), the pooled results should yield weak correlations. 
Finally, Models 3 and 6 test our main theoretical expectation regarding the interaction between the strength of social democratic governments and the electoral relevance of outsiders and insiders, respectively. The positive and statistically significant effect of the interaction term in Model 3 is in line with our hypothesis. The larger the share of outsiders within the social democratic electorate, the more outsider-friendly are labor market reforms under left government. Figure 4 visualizes this interaction effect. From very low levels of outsiders' electoral relevance until about 0.25 , the marginal effect of social democratic government strengths' on outsiders' reform output is negative. In that case, the increasing presence of social democrats in government leads to labor market reforms that worsen the situation of outsiders. This is essentially the insider/outsider story of Rueda (2007), which still applies to countries with a heavily insider-dominated working class. When outsiders, however, become more relevant (at about 0.25 ), as they have in various countries, then the negative effect ceases. More speculatively, judging from the figure, one could extrapolate that if outsiders become even more relevant in the future, we might witness a positive marginal effect of social democratic government strengths' on outsiders' reform output, and thus a reversal of insider/outsider bias of social democratic parties.

Moving on to the substantive significance of this finding, we find a marginal effect of about -0.025 on our outsiders' reform measure when the electoral relevance of outsiders is low (about 0.18). This sounds like a negligible effect at first sight. However, an one-point change in government strength is not very telling because the cabinet share of social democratic parties in the 19 European countries under study usually varies quite drastically from one election to another (see Figure SI2.6 in the Appendix for country-specific cabinet shares). ${ }^{14}$ A more realistic fifty-point change in the strength of social democratic governments leads to a 1.25 point decrease in our outsiders' reform measure. In other words, if social democrats can improve their cabinet share by 50 percentage points, it is associated with at about 1.25 comprehensive policy changes that negatively affect outsiders, but only if outsiders are electorally almost irrelevant. If it comes to a wholesale government alteration, which equals a 100 percentage point change, it is related to a about two and a half comprehensive policy changes that worsen the situation of outsiders. These are again quite substantive effects given that the standard deviation of the outsiders' reform measure is 2.2. Looking at the effective policy changes that took place in a country over time (see Figure SI2.2 in the 
Table 1: Left government, electoral relevance and labor market reforms

\begin{tabular}{|c|c|c|c|c|c|c|}
\hline & \multicolumn{3}{|c|}{ Reform Effect on Outsiders } & \multicolumn{3}{|c|}{ Reform Effect on Insiders } \\
\hline & M1 & M2 & M3 & M4 & M5 & M6 \\
\hline L.OutsiderReform & $\begin{array}{l}0.102 \\
(0.10)\end{array}$ & $\begin{array}{l}0.121 \\
(0.09)\end{array}$ & $\begin{array}{c}0.087 \\
(0.10)\end{array}$ & & & \\
\hline L.InsiderReform & & & & $\begin{array}{l}0.187 \\
(0.16)\end{array}$ & $\begin{array}{l}0.203 \\
(0.16)\end{array}$ & $\begin{array}{l}0.224 \\
(0.15)\end{array}$ \\
\hline LeftGov & & $\begin{array}{c}-0.011 \\
(0.01)\end{array}$ & $\begin{array}{c}-0.074^{*} \\
(0.03)\end{array}$ & & $\begin{array}{l}-0.007 \\
(0.01)\end{array}$ & $\begin{array}{l}-0.123 \\
(0.08)\end{array}$ \\
\hline ElRelOutsider & & $\begin{array}{l}2.871 \\
(8.15)\end{array}$ & $\begin{array}{l}-8.987 \\
(8.57)\end{array}$ & & $\begin{array}{l}4.498 \\
(9.37)\end{array}$ & $\begin{array}{l}8.201 \\
(11.89)\end{array}$ \\
\hline ElRelInsider & & $\begin{array}{l}-4.002 \\
(19.32)\end{array}$ & $\begin{array}{c}-14.987 \\
(21.97)\end{array}$ & & $\begin{array}{l}2.988 \\
(11.94)\end{array}$ & $\begin{array}{l}2.889 \\
(11.30)\end{array}$ \\
\hline LeftGov X ElRelOutsider & & & $\begin{array}{l}0.267^{*} \\
(0.11)\end{array}$ & & & \\
\hline LeftGov X ElRelInsider & & & & & & $\begin{array}{l}0.423 \\
(0.29)\end{array}$ \\
\hline Outsidershare & $\begin{array}{l}2.044 \\
(12.55)\end{array}$ & & & $\begin{array}{l}-3.499 \\
(18.24)\end{array}$ & & \\
\hline Insidershare & $\begin{array}{l}20.188 \\
(15.20)\end{array}$ & & & $\begin{array}{l}17.095 \\
(15.34)\end{array}$ & & \\
\hline L.Unemploymentrate & $\begin{array}{l}0.022 \\
(0.07)\end{array}$ & $\begin{array}{c}-0.036 \\
(0.08)\end{array}$ & $\begin{array}{l}0.012 \\
(0.07)\end{array}$ & $\begin{array}{l}0.004 \\
(0.08)\end{array}$ & $\begin{array}{c}-0.038 \\
(0.08)\end{array}$ & $\begin{array}{c}-0.062 \\
(0.07)\end{array}$ \\
\hline L.RealGDPgrowth & $\begin{array}{l}0.275^{+} \\
(0.12)\end{array}$ & $\begin{array}{l}0.295^{+} \\
(0.13)\end{array}$ & $\begin{array}{l}0.334^{*} \\
(0.14)\end{array}$ & $\begin{array}{l}0.211 \\
(0.17)\end{array}$ & $\begin{array}{l}0.211 \\
(0.16)\end{array}$ & $\begin{array}{l}0.117 \\
(0.07)\end{array}$ \\
\hline L.UnionDensity & $\begin{array}{c}-0.146 \\
(0.12)\end{array}$ & $\begin{array}{r}-0.167 \\
(0.14)\end{array}$ & $\begin{array}{r}-0.197 \\
(0.15)\end{array}$ & $\begin{array}{l}-0.026 \\
(0.07)\end{array}$ & $\begin{array}{c}-0.029 \\
(0.06)\end{array}$ & $\begin{array}{l}0.024 \\
(0.09)\end{array}$ \\
\hline Constant & $\begin{array}{l}-2.331 \\
(6.62)\end{array}$ & $\begin{array}{l}6.954 \\
(4.07)\end{array}$ & $\begin{array}{l}13.500^{*} \\
(5.51)\end{array}$ & $\begin{array}{r}-4.247 \\
(8.89) \\
\end{array}$ & $\begin{array}{c}-0.293 \\
(4.97)\end{array}$ & $\begin{array}{l}-2.518 \\
(5.90)\end{array}$ \\
\hline Country Fixed Effects & $\checkmark$ & $\checkmark$ & $\checkmark$ & $\checkmark$ & $\checkmark$ & $\checkmark$ \\
\hline$R^{2}$ & 0.136 & 0.149 & 0.185 & 0.235 & 0.240 & 0.288 \\
\hline$A I C$ & 474.581 & 474.980 & 472.484 & 418.420 & 419.662 & 414.891 \\
\hline$B I C$ & 490.505 & 493.558 & 493.715 & 434.344 & 438.240 & 436.122 \\
\hline$N$ & 105 & 105 & 105 & 105 & 105 & 105 \\
\hline
\end{tabular}

Notes: Pooled OLS-regression with lagged dependent variable, country fixed effects and country-clustered SEs. Standard errors in parentheses: ${ }^{+} p<0.1,{ }^{*} p<0.05,{ }^{* *} p<0.01,{ }^{* * *} p<0.001$. 

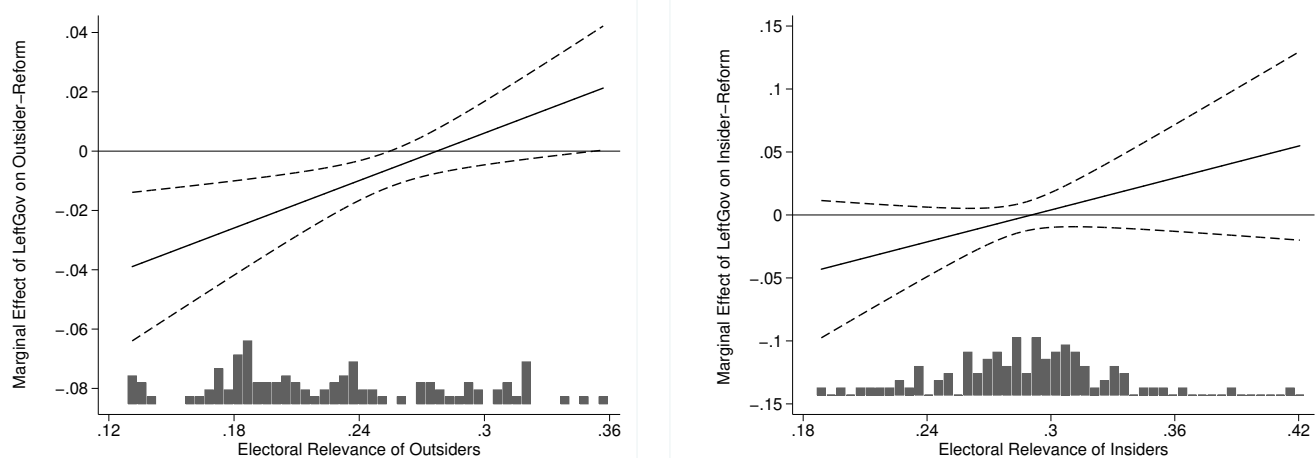

Figure 4: Interaction LeftGov with electoral relevance of outsiders and insiders on reform effects data (each based on Model 3 and 6 in Table 1 )

Appendix), it becomes clear that our effects are substantively relevant: many actual policy changes are of a smaller magnitude.

Model 6 in Table 1 shows that mirror image of this hypothesis, i.e. the interaction between the electoral relevance of insiders and left governments on insider-friendly reforms, fails to reach conventional levels of statistical significance. This stands in contrast to Model 3 and all other interactions that will follow in the next section. The right-hand side of Figure 4 visualizes this conditional relationship. Clearly, the effect goes in the expected direction but is imprecisely estimated. This is for two reasons. This first part of the analysis only includes countries from Continental and Southern Europe, thus substantially reducing sample size. In addition, the distribution of insiders' electoral relevance is much more centered than those of outsiders on the left-hand plot in Figure 4, resulting in fewer cases on the margins with reduces precision. In the light of these circumstances and given that at least the direction of the effect confirms our expectations, we contend that Model 6 should not fundamentally invalidate our all in all affirmative evidence of the main hypothesis. The next section, which is based on more broadly available spending data, will demonstrate that we can recover this effect with more statistical power.

\section{Electoral Relevance and Labor Market Policy Spending}

As a last step, we complement our evaluation of policy reforms with more conventional dependent variables, i.e. measures based on spending data. The following analyses are based on a larger sample of countries and thus represent a welcome validation of our previous 
results based on original, new data. Table 2 presents the results of spending on active and passive labor market policy.

Again, Model 1 and Model 5 indicate that the group size of insiders and outsiders is in itself not directly related to the level of spending on active or passive labor market policy. We tested further in Model 2 and Model 6 whether the strength of social democratic governments or our measures of the electoral relevance of insiders and outsiders is associated with our two spending outcomes. As anticipated, the results show that there is hardly any direct correlation between our three explanatory variables and our two dependent variables. The one exception to this pattern is the significant negative correlation between the electoral relevance of insiders and ALMP spending. Since ALMP is clearly the least beneficial policy for insiders, perhaps even other than social democratic parties lower spending in that domain if insiders form a large part of the electorate. 
Table 2: Left government, electoral relevance and labor market spending

\begin{tabular}{|c|c|c|c|c|c|c|c|c|}
\hline & \multicolumn{4}{|c|}{ ALMP Spending (in \% of GDP) } & \multicolumn{4}{|c|}{ PLMP Spending (in \% of GDP) } \\
\hline & M1 & M2 & M3 & M4 & M5 & M6 & M7 & M8 \\
\hline L.ALMP & $\begin{array}{l}0.750^{* * *} \\
(0.06)\end{array}$ & $\begin{array}{l}0.751^{* * *} \\
(0.05)\end{array}$ & $\begin{array}{l}0.741^{* * *} \\
(0.05)\end{array}$ & $\begin{array}{l}0.757^{* * *} \\
(0.05)\end{array}$ & & & & \\
\hline L.PLMP & & & & & $\begin{array}{l}0.870^{* * *} \\
(0.09)\end{array}$ & $\begin{array}{l}0.876^{* * *} \\
(0.08)\end{array}$ & $\begin{array}{l}0.866^{* * *} \\
(0.07)\end{array}$ & $\begin{array}{l}0.875^{* * *} \\
(0.08)\end{array}$ \\
\hline Leftgov & & $\begin{array}{l}0.000 \\
(0.00)\end{array}$ & $\begin{array}{l}-0.001^{*} \\
(0.00)\end{array}$ & $\begin{array}{l}0.001 \\
(0.00)\end{array}$ & & $\begin{array}{l}0.001 \\
(0.00)\end{array}$ & $\begin{array}{l}-0.002^{+} \\
(0.00)\end{array}$ & $\begin{array}{l}0.002 \\
(0.00)\end{array}$ \\
\hline ElRelOutsider & & $\begin{array}{c}-0.379 \\
(0.25)\end{array}$ & $\begin{array}{l}-0.542^{*} \\
(0.26)\end{array}$ & $\begin{array}{l}-0.381 \\
(0.24)\end{array}$ & & $\begin{array}{l}-0.313 \\
(0.29)\end{array}$ & $\begin{array}{c}-0.693^{*} \\
(0.30)\end{array}$ & $\begin{array}{l}-0.315 \\
(0.30)\end{array}$ \\
\hline ElRelInsider & & $\begin{array}{c}-0.562^{*} \\
(0.20)\end{array}$ & $\begin{array}{l}-0.684^{* *} \\
(0.21)\end{array}$ & $\begin{array}{l}-0.527^{*} \\
(0.20)\end{array}$ & & $\begin{array}{l}-1.023 \\
(0.65)\end{array}$ & $\begin{array}{l}-1.285^{+} \\
(0.61)\end{array}$ & $\begin{array}{l}-0.977 \\
(0.70)\end{array}$ \\
\hline Leftgov X ElRelOutsider & & & $\begin{array}{l}0.006^{* *} \\
(0.00)\end{array}$ & & & & $\begin{array}{l}0.015^{*} \\
(0.01)\end{array}$ & \\
\hline Leftgov X ElRelInsider & & & & $\begin{array}{l}-0.003 \\
(0.00)\end{array}$ & & & & $\begin{array}{l}-0.005 \\
(0.01)\end{array}$ \\
\hline Outsidershare & $\begin{array}{l}-0.242 \\
(0.55)\end{array}$ & & & & $\begin{array}{l}0.060 \\
(0.61)\end{array}$ & & & \\
\hline Insidershare & $\begin{array}{l}-0.897^{+} \\
(0.43)\end{array}$ & & & & $\begin{array}{c}-0.799 \\
(1.26)\end{array}$ & & & \\
\hline L.unemploymentrate & $\begin{array}{c}-0.004 \\
(0.00)\end{array}$ & $\begin{array}{c}-0.004 \\
(0.00)\end{array}$ & $\begin{array}{c}-0.003 \\
(0.00)\end{array}$ & $\begin{array}{l}-0.004^{+} \\
(0.00)\end{array}$ & $\begin{array}{l}-0.025^{+} \\
(0.01)\end{array}$ & $\begin{array}{l}-0.025^{*} \\
(0.01)\end{array}$ & $\begin{array}{l}-0.023^{*} \\
(0.01)\end{array}$ & $\begin{array}{l}-0.025^{*} \\
(0.01)\end{array}$ \\
\hline L.RealGDPgrowth & $\begin{array}{l}-0.009^{* * *} \\
(0.00)\end{array}$ & $\begin{array}{l}-0.010^{* * *} \\
(0.00)\end{array}$ & $\begin{array}{l}-0.009^{* * *} \\
(0.00)\end{array}$ & $\begin{array}{l}-0.010^{* * *} \\
(0.00)\end{array}$ & $\begin{array}{l}-0.029^{* * *} \\
(0.00)\end{array}$ & $\begin{array}{l}-0.029^{* * *} \\
(0.00)\end{array}$ & $\begin{array}{l}-0.028^{* * *} \\
(0.00)\end{array}$ & $\begin{array}{l}-0.028^{* * *} \\
(0.00)\end{array}$ \\
\hline L.Uniondensity & $\begin{array}{l}-0.004 \\
(0.00)\end{array}$ & $\begin{array}{l}-0.001 \\
(0.00)\end{array}$ & $\begin{array}{l}-0.000 \\
(0.00)\end{array}$ & $\begin{array}{l}-0.001 \\
(0.00)\end{array}$ & $\begin{array}{l}0.006 \\
(0.01)\end{array}$ & $\begin{array}{l}0.008 \\
(0.01)\end{array}$ & $\begin{array}{l}0.010^{+} \\
(0.01)\end{array}$ & $\begin{array}{l}0.009 \\
(0.01)\end{array}$ \\
\hline Constant & $\begin{array}{l}0.687^{* *} \\
(0.20)\end{array}$ & $\begin{array}{l}0.503^{* * *} \\
(0.10)\end{array}$ & $\begin{array}{l}0.539^{* * *} \\
(0.11)\end{array}$ & $\begin{array}{l}0.466^{* * *} \\
(0.11)\end{array}$ & $\begin{array}{l}0.416 \\
(0.64)\end{array}$ & $\begin{array}{l}0.489 \\
(0.33) \\
\end{array}$ & $\begin{array}{l}0.543 \\
(0.32) \\
\end{array}$ & $\begin{array}{l}0.438 \\
(0.37)\end{array}$ \\
\hline Country Fixed Effects & $\checkmark$ & $\checkmark$ & $\checkmark$ & $\checkmark$ & $\checkmark$ & $\checkmark$ & $\checkmark$ & $\checkmark$ \\
\hline$R^{2}$ & 0.956 & 0.957 & 0.958 & 0.957 & 0.963 & 0.965 & 0.966 & 0.965 \\
\hline$A I C$ & -575.400 & -576.671 & -580.706 & -576.716 & -163.015 & -169.832 & -175.097 & -168.741 \\
\hline$B I C$ & -554.344 & -552.105 & -552.631 & -548.641 & -141.959 & -145.266 & -147.022 & -140.666 \\
\hline$N$ & 247 & 247 & 247 & 247 & 247 & 247 & 247 & 247 \\
\hline
\end{tabular}

Notes: Pooled OLS-regression with lagged dependent variable, country fixed effects and country-clustered SEs.

Standard errors in parentheses: ${ }^{+} p<0.1,{ }^{*} p<0.05,{ }^{* *} p<0.01,{ }^{* * *} p<0.001$. 

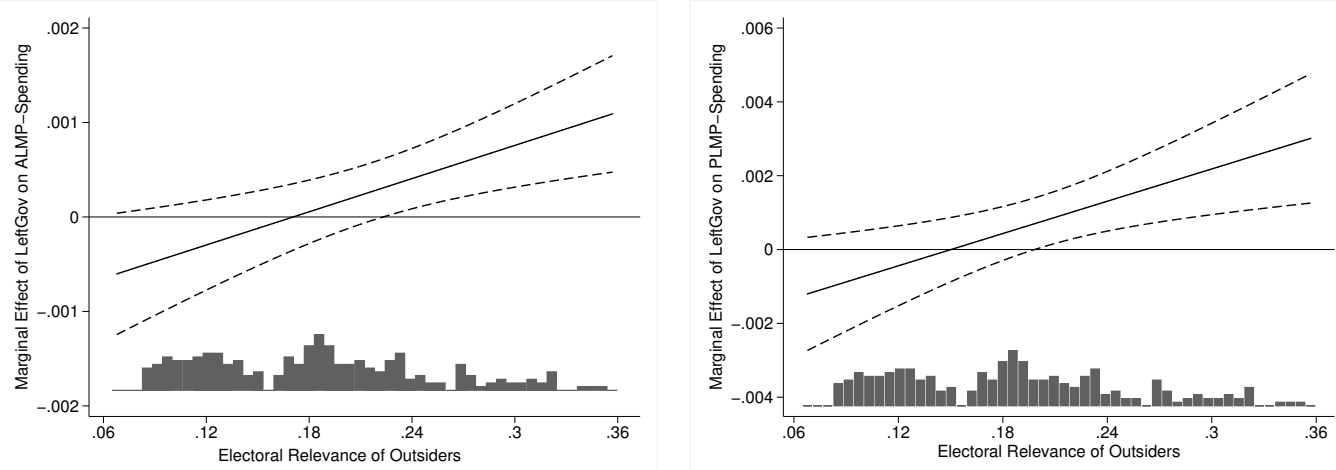

Figure 5: Interaction LeftGov with electoral relevance of outsiders on ALMP and PLMP spending with 95\%-confidence intervals (based on Model 3 and 7 in Table 2p. Histograms show the distribution of the electoral relevance of outsiders.

Models 3 and 7, are another test of our core hypothesis and provide strong and consistent evidence in line with our expectations. For both labor market outcome measures, the interaction between the strength of social democratic governments and the electoral relevance of outsiders is statistically significant and positive. This means that the stronger social democratic governments are, the more they pursue pro-outsider policies like active and passive labor market policies if and only if the electoral relevance of outsiders is sufficiently high. As hypothesized, the impact of social democratic governments depends upon the electoral relevance of outsiders. Figure 5 visualizes the interaction effect of the two continuous variables by presenting the marginal effects. In both cases, for low values of our outsiders' electoral relevance measure, we find no effect of social democratic governments on the level of active or passive labor market policy spending. When outsiders become sufficiently relevant (at about 0.22 for ALMP and at about 0.20 for PLMP), we do find a positive and significant marginal effect of social democratic government strengths' on active and passive labor market policy spending.

For an outsider value of 0.3 on our electoral relevance measure, we find a positive marginal effect of about 0.001 percentage points for ALMP and 0.002 percentage points for PLMP spending (both measured in \% of GDP) for an one-point change in the social democratic government strength. A more realistic 50 or even 100 percentage point change in the strength of social democratic governments, would be associated with a yearly percentage point increase in ALMP spending equal to 0.05 or 0.10 and PLMP spending equal to 0.10 or 0.20 . Given that the standard deviation of ALMP and PLMP spending is 0.13 and 0.34, these are 
substantial changes in labor market policy spending. We can further contextualize the effect by looking at ALMP/PLMP levels of particular countries (see Figure SI2.7 and SI2.8 in the Appendix). In the case of Spain, for example, the share of GDP devoted to ALMP is about 0.70. A 50 or 100 percentage point change in Left government would therefore lead to a considerable 7 or 14 percent yearly increase in ALMP spending. In contrast, in a counterfactual Spain with outsiders being only half as relevant in the social democratic support coalition, a similar increase in left government seats would not result in higher ALMP spending.

As a last step, we tested in Model 4 and Model 8 the reverse idea in the spirit of a placebo test. Given that both active and passive labor market policy spending can be seen as a prooutsider policy, the interaction between the strength of social democratic governments and the electoral relevance of insiders should be either not significant or have a negative effect. The results indicate that the interaction term is not significant for PLMP spending and for ALMP spending. Figure SI2.5 in the Appendix visualizes the interaction effects and confirms that the marginal effects of social democratic governments on ALMP and PLMP spending are not significant.

\section{Discussion and Conclusion}

This article provides two main takeaways. First, we show that the often-made assumption of widespread political apathy among the more vulnerable part of labor does not hold under empirical scrutiny. Especially in Continental and Southern Europe, insiders and outsiders are of comparable electoral relevance. Given the structural developments of the past decades, an ongoing spread of atypical work is highly likely, which will make labor market outsiders even more relevant in the electoral arena.

Second, and more importantly, the described variation in electoral relevance is politically consequential. This is the case with respect to both actual labor market reform outputs and spending on different kinds of labor market policy. We demonstrate that a higher relative electoral weight of labor market outsiders is consistently related to more frequent prooutsider labor market reforms and increased spending on ALMP and PLMP whenever left parties have a substantial share in government. From the perspective of electoral relevance, 
social democratic governments in the 1980s and 1990s have implemented reforms biased against outsiders because insiders were their core electorate. As outsiders, however, become more electorally relevant for social democratic parties over time, we witness a shift in social democratic labor market policy-making away from the pro-insider bias emphasized in the seminal insider/outsider literature towards more inclusive, pro-outsider oriented policies.

This result has several important implications. First of all, our results show remarkable responsiveness of parties to their voters' demands, even when studying the issue within political blocks. While policymakers do not blindly follow the mood of their supporters and certainly retain some room for strategic maneuver, we demonstrate that policy implementation is systematically related to the relative electoral weight of different groups within the support coalition. In contrast to much of the existing work, we do not study what parties promise in their manifestos but what they really $d o$ in terms of policy output. This finding ties in with the idea that parties anticipate and deliver what their pivotal voter wants in order to maximize votes and increase chances for re-election (Stimson et al., 1995). This is not a trivial result, in particular in times when mainstream parties' ability and willingness to respond to "the ordinary voter" is increasingly challenged, not least by populist parties from various ideological backgrounds.

What is more, the electoral relevance approach we proposed in this paper has a more general takeaway for research on responsiveness in post-industrial societies, which are characterized by increasingly heterogeneous electorates. Existing studies often examine preferences of specific constituencies without taking into account differences in size and, thus, electoral relevance. To get a more encompassing understanding of political decision-making and responsiveness, research needs to move beyond focusing solely particular subgroups' preferences but also incorporate their specific electoral weight. A notable recent example is Evans and Tilley's (2017) analysis of long-term changes in class voting in Britain, which explicitly takes into account the varying size of different societal strata over time.

Finally, we want to address a caveat of our approach. The political mobilization of particular subgroups of the electorate partly depends on parties' programmatic offers and what they offer in turn hinges on the relative electoral relevance of each group. Iteratively assessing how strongly an increase in electoral relevance affects party programs and what such a 
programmatic move means for the political mobilization among the targeted groups is at the heart of political science. Ideally one would combine supply- and demand-side in a dynamic framework. However, the apparent endogeneity issues pose thorny empirical questions. We believe that acknowledging the importance of both supply- and demand-side and assessing them separately is a first (but not the last) step towards a more encompassing understanding of both party strategies and citizen's political decisions. Our analysis thus highlights new avenues for further research. For example, studies concerned with the moderating impact of social democratic (or any party's) policy decisions on the share and prevalence of atypical employment might incorporate our findings to arrive at a more encompassing picture of feedback effects and policy-making in post-industrial societies. 


\section{References}

Abou-Chadi, T. and Wagner, M. (2019). The electoral appeal of party strategies in postindustrial societies: when can the Mainstream Left succeed? Journal of Politics, forthcoming.

Adams, J., Clark, M., Ezrow, L., and Glasgow, G. (2004). Understanding Change and Stability in Party Ideologies: Do Parties Respond to Public Opinion or to Past Election Results? British Journal of Political Science, 34(4):589-610.

Armingeon, K., Wenger, V., Wiedemeier, F., Isler, C., Knöpfel, L., Weisstanner, D., and Engler, S. (2018). Comparative political data set 1960-2016.

Autor, D. (2010). The polarization of job opportunities in the us labor market: Implications for employment and earnings. Center for American Progress and The Hamilton Project.

Autor, D. H., Levy, F., and Murnane, R. J. (2003). The Skill Content of Recent Technological Change: An Empirical Exploration. The Quarterly Journal of Economics, pages 12791333 .

Axelrod, R. (1972). Where the votes come from: An analysis of electoral coalitions, 19521968. American political science review, 66(1):11-20.

Beck, N. (2001). Time-series-cross-section data: What have we learned in the past few years? Annual review of political science, 4(1):271-293.

Beck, N. and Katz, J. N. (1995). What to do (and not to do) with time-series cross-section data. American political science review, 89(3):634-647.

Bélanger, É. and Meguid, B. M. (2008). Issue salience, issue ownership, and issue-based vote choice. Electoral Studies, 27(3):477-491.

Beramendi, P., Häusermann, S., Kitschelt, H., and Kriesi, H. (2015). The politics of advanced capitalism. Cambridge University Press, Cambridge.

Best, R. E. (2011). The declining electoral relevance of traditional cleavage groups. European Political Science Review, 3(2):279-300.

Blais, A. and Dobrzynska, A. (1998). Turnout in electoral democracies. European Journal of Political Research, 33(2):239-261.

Bonoli, G. (2010). The political economy of active labor-market policy. Politics E Society, 38(4):435-457.

Bonoli, G. (2013). The origins of active social policy: Labour market and childcare policies in a comparative perspective. Oxford University Press.

Bornschier, S. (2010). Cleavage politics and the populist right: the new cultural conflict in Western Europe. Temple University Press, Philadelphia.

Bremer, B. (2018). The missing left? Economic crisis and the programmatic response of social democratic parties in Europe. Party Politics, 24(1):23-38.

Burgoon, B. and Dekker, F. (2010). Flexible employment, economic insecurity and social policy preferences in europe. Journal of European Social Policy, 20(2):126-141.

Clasen, J. and Siegel, N. A. (2007). Investigating welfare state change: the 'dependent variable problem' in comparative analysis. Edward Elgar Publishing. 
De Grip, A., Hoevenberg, J., and Willems, E. (1997). Atypical employment in the european union. International Labour Review, 136:49.

Emmenegger, P. (2009). Barriers to entry: Insider/outsider politics and the political determinants of job security regulations. Journal of European Social Policy, 19(2):131-146.

Emmenegger, P., Häusermann, S., Palier, B., and Seeleib-Kaiser, M., editors (2012). The age of dualization : the changing face of inequality in deindustrializing societies. Oxford University Press, Oxford.

Emmenegger, P., Marx, P., and Schraff, D. (2015). Labour market disadvantage, political orientations and voting: how adverse labour market experiences translate into electoral behaviour. Socio-Economic Review, 13(2):189-213.

Evans, G. and Tilley, J. (2017). The New Politics of Class: The Political Exclusion of the British Working Class. Oxford University Press, Oxford, New York.

Garritzmann, J., Häusermann, S., Palier, B., and Zollinger, C. (2016). WOPSI-The World Politics of Social Investment.

Gidron, N. and Hall, P. A. (2017). The politics of social status: economic and cultural roots of the populist right. The British Journal of Sociology, 68:S57-S84.

Gingrich, J. and Häusermann, S. (2015). The decline of the working-class vote, the reconfiguration of the welfare support coalition and consequences for the welfare state. Journal of European Social Policy, 25(1):50-75.

Hainmueller, J., Mummolo, J., and Xu, Y. (2018). How much should we trust estimates from multiplicative interaction models? simple tools to improve empirical practice. Political Analysis.

Häusermann, S. (2010). The Politics of Welfare State Reform in Continental Europe: Modernization in Hard Times. Cambridge University Press, Cambridge.

Häusermann, S., Kurer, T., and Schwander, H. (2015). High-skilled outsiders? labor market vulnerability, education and welfare state preferences. Socio-Economic Review, 13(2):23558.

Häusermann, S., Kurer, T., and Schwander, H. (2016). Sharing the Risk? Households, Labor Market Vulnerability, and Social Policy Preferences in Western Europe. The Journal of Politics, 78(4):1045-1060.

Häusermann, S., Picot, G., and Geering, D. (2013). Review Article: Rethinking Party Politics and the Welfare State - Recent Advances in the Literature. British Journal of Political Science, 43(01):221-240.

Häusermann, S. and Schwander, H. (2012). Varieties of Dualization? In Emmenegger, P., Häusermann, S., Palier, B., and Seeleib-Kaiser, M., editors, The age of dualization : the changing face of inequality in deindustrializing societies, pages 27-51. Oxford University Press, Oxford.

Hemerijck, A. (2015). The quiet paradigm revolution of social investment. Social Politics, $22(2): 242-256$

Hübscher, E. (2017). Party governments, clientelistic reforms, and varying levels of political constraints. Comparative European Politics, 15(6):848-871. 
Karreth, J., Polk, J. T., and Allen, C. S. (2013). Catchall or catch and release? The electoral consequences of social democratic parties' march to the middle in Western Europe. Comparative Political Studies, 46(7):791-822.

Kitschelt, H. (1994). The Transformation of European Social Democracy. Cambridge University Press, Cambridge.

Klüver, H. (2018). Setting the Party Agenda: Interest Groups, Voters and Issue Attention. British Journal of Political Science, pages 1-22.

Klüver, H. and Spoon, J.-J. (2016). Who responds? Voters, parties and issue attention. British Journal of Political Science, 46(3):633-654.

Korpi, W. (1983). The democratic class struggle. Routledge and Kegan Paul, London.

Kurer, T. (2017). The Declining Middle: Political Reactions to Occupational Change. ECPR General Conference Oslo, September.

Leighley, J. E. and Nagler, J. (2013). Who votes now?: Demographics, issues, inequality, and turnout in the United States. Princeton University Press, Princeton.

Lindvall, J. and Rueda, D. (2014). The insider-outsider dilemma. British Journal of Political Science, 44(02):460-475.

Marx, P. (2014). Labour market risks and political preferences: The case of temporary employment. European Journal of Political Research, 53(1):136-159.

Morel, N., Palier, B., and Palme, J. (2012). Towards a social investment welfare state? : ideas, policies and challenges. Policy, Bristol.

OECD (2016). OECD Employment Outlook 2016. Technical report, OECD Publishing, Paris.

Oesch, D. (2006). Redrawing the class map: stratification and institutions in Britain, Germany, Sweden and Switzerland. Palgrave Macmillan, Basingstoke [England]; New York.

Oesch, D. (2008). The changing shape of class voting: An individual-level analysis of party support in britain, germany and switzerland. European Societies, 10(3):329-355.

Oesch, D. and Rennwald, L. (2018). Electoral competition in Europe's new tripolar political space: Class voting for the left, centre-right and radical right. European Journal of Political Research, page online first.

Palier, B. and Thelen, K. (2010). Institutionalizing dualism: Complementarities and change in France and Germany. Politics $\mathcal{E} 3$ Society, 38(1):119-148.

Petrocik, J. R. (1996). Issue Ownership in Presidential Elections, with a 1980 Case Study. American Journal of Political Science, 40(3):825-850.

Picot, G. and Menéndez, I. (2017). Political parties and non-standard employment: an analysis of France, Germany, Italy and Spain. Socio-Economic Review.

Rehm, P. (2009). Risks and redistribution: An individual-level analysis. Comparative Political Studies, 42(7):855-881.

Rennwald, L. and Evans, G. (2014). When Supply Creates Demand: Social Democratic Party Strategies and the Evolution of Class Voting. West European Politics, 37(5):11081135. 
Rovny, A. E. and Rovny, J. (2017). Outsiders at the ballot box: operationalizations and political consequences of the insider-outsider dualism. Socio-Economic Review.

Rueda, D. (2005). Insider-Outsider Politics in Industrialized Democracies: The Challenges to Social Democratic Parties. American Political Science Review, 99(1):61-74.

Rueda, D. (2006). Social democracy and active labour-market policies: insiders, outsiders and the politics of employment promotion. British Journal of Political Science, 36(3):385406 .

Rueda, D. (2007). Social Democracy Inside Out. Partisanship and Labor Market Policy in Industrialized Democracies. Oxford University Press, Oxford.

Rydgren, J. (2013). Class politics and the radical right. Routledge, London.

Schwander, H. (2018). Are social democratic parties insider parties? Electoral strategies of social democratic parties in Western Europe in the age of dualization. Comparative European Politics.

Schwander, H. and Häusermann, S. (2013). Who is in and who is out? A risk-based conceptualization of insiders and outsiders. Journal of European Social Policy, 23(3):248269.

Steenbergen, M. R., Edwards, E. E., and de Vries, C. E. (2007). Who's Cueing Whom?: Mass-Elite Linkages and the Future of European Integration. European Union Politics, $8(1): 13-35$.

Stimson, J. A., Mackuen, M. B., and Erikson, R. S. (1995). Dynamic Representation. The American Political Science Review, 89(3):543-565.

Vlandas, T. (2013). Mixing apples with oranges? partisanship and active labour market policies in europe. Journal of European Social Policy, 23(1):3-20. 


\title{
Notes
}

\begin{abstract}
${ }^{1}$ Outsiders are either part-time workers (less than 30 hours), temporary workers or unemployed. Insiders are workers with a full-time permanent working contract. The residual group, which Rueda calls "upscales", are mainly high-skilled professionals in non-working-class jobs. See the section on operationalization for a more detailed discussion of advantages and disadvantages of alternative classifications.
\end{abstract}

${ }^{2}$ To be clear, Figure 1 shows policy changes rather than levels. We do not mean to claim that outsiders are better protected in the labor market than insiders. The literature on insider/outsider divides and labor market flexibilization (Rueda, 2005, Palier and Thelen, 2010, Emmenegger et al. 2012) is unequivocal on the fact that insiders enjoy higher employment protection than outsiders, have better access to unemployment benefits, and that active labor market policies remain underdeveloped in most countries. But since we are interested in explaining policy change over time within a country, our focus on labor market reforms rather than levels of protection stands to reason.

${ }^{3}$ In Spain, for example, the recovery after the Great Recession is associated with a continued increase of already widespread atypical work as temporary contracts account for the "large majority" of new hires (OECD 2016).

${ }^{4}$ We replicated Gingrich and Häusermann's occupational classes to calculate the share of labor market outsiders among their groups. Table SI2.1 in the Appendix reports outsider shares within the middle class, manual workers, and routine workers. As expected, most manual blue-collar workers can be considered archetypical labor market insiders: only few are affected by atypical employment. The middle classes are slightly more affected by such atypical labor market contracts, especially in Continental and Southern Europe (see also Häusermann et al. 2015). Finally, outsiders cluster in all the countries mainly in the broadly operationalized group of routine workers.

${ }^{5}$ Note that Gingrich/Häusermann categorize low-skilled service and office workers into this group. Routineness is understood differently in the task-based literature in labor economics, which defines routine work as "carrying out a limited and well-defined set of cognitive and manual activities, those that can be accomplished by following explicit rules" (Autor et al. 2003), meaning primarily semi-skilled blue- and white-collar jobs.

${ }^{6}$ Given that large shifts in positions are relatively rare, most of the literature is concerned with positional shifts within a political block or with varying salience of distinct policies, i.e. differential emphasis of one or the other issue, for example in party manifestos (see, e.g., Bremer 2018 for a more detailed discussion).

7 Vlandas (2013) has pointed out that political parties implement different types of active labor market policies. A descriptive breakdown of ALMP reforms into different subtypes (following (Bonoli 2010) and cabinet ideology confirms that center-left compared to center-right cabinets enacted more upskilling reforms and less employment incentive reforms (see Figure SI2.3 in the appendix).

${ }^{8}$ For a slightly modified more recent application, see Best (2011).

${ }^{9}$ For a comparison of these approaches, see Rovny and Rovny (2017).

${ }^{10}$ These countries are Austria, Belgium, Switzerland, Czech Republic, Germany, Denmark, Spain, Finland, France, Greece, Great Britain, Hungary, Ireland, Italy, the Netherlands, Norway, Poland, Portugal and Sweden. All countries have a per capita GDP higher than 25'000 international dollars and more than 3 million inhabitants (for a similar case selection see Beramendi et al. 2015 p. 4).

${ }^{11}$ Based on Armingeon et al. (2018), the following parties were classified as the main social democratic parties: SP.A and PS (Belgium), SP (Switzerland), CSSD (Czech Republic), SPD (Germany), SD (Denmark), PSOE (Spain), SDP (Finland), PS (France), Labour (Great Britain), MSZP (Hungary), Labour (Ireland), Ulivo/PD (Italy), PvdA (Netherlands), A (Norway), SLD (Poland), PS (Portugal), SAP (Sweden).

${ }^{12}$ It is therefore not about the question whether outsiders and/or insiders prefer these policies or not. For example, it may very well be the case that outsiders prefer rigid employment protection of permanent work contracts (Emmenegger, 2009), even though they are not are not directly affected by such changes and hence do not profit from such legislation.

${ }^{13}$ We can only calculate turnout and vote choice biannually due to data availability of the ESS. Since we are dealing with slow-moving averages, we linearly impute the missing years, but only if there are observations 
one year before and one year after. We also ran all the models without the imputation and the linear imputation does not change the substantive findings presented in the next part.

${ }^{14}$ In a majority of the cases, it is common to witness 50-100 percentage point changes (Czech Republic, Denmark, Germany, Spain, France, Greece, Italy, Norway, Poland, Portugal, Sweden, UK, Hungary) and in all the other countries, with the exception of Switzerland, 25-50 percentage point changes are no exception (Austria, Belgium, Finland, Ireland, the Netherlands). 


\section{Appendix: Electoral Relevance by Country}

Description: The first two columns show the relative group shares derived from EU-SILC, the next two columns display the predicted probability to turnout for both groups and the sixth and seventh column give the calculated probabilities to vote for the social democratic party. The fifth and eight column shows the national average in turnout and the national average of the social democratic vote share. Finally, the last four columns to the right-hand side of Table A1 represent our estimates of electoral relevance, i.e. the product of the three parameters for each group divided by the product of the two national parameters, as well as the difference and the ratio in electoral relevance between insiders and outsiders. Take for example the case in the first row, Denmark. According to our data, $44.3 \%$ of the votes for the Danish Social Democrats come from insiders and only $11.9 \%$ from outsiders. The total adds up to $100 \%$ with the few votes of labor market upscales, which are not considered typical supporters of social democratic parties, and the considerable vote share among people not in the labor force, mainly pensioners, who are an unlikely driving force behind labor market policy. Reducing the sample to the labor force, as is often done in the insider/outsider literature, would obviously increase vote shares massively but we deem the current numbers both more telling and more intuitive. 
Table A1: Electoral Relevance of Insiders and Outsiders for Social Democrats, pooled years 2002-2016 (unconditional models)

\begin{tabular}{|c|c|c|c|c|c|c|c|c|c|c|c|c|}
\hline & \multicolumn{2}{|c|}{ Group Share } & \multicolumn{3}{|c|}{ Turnout } & \multicolumn{3}{|c|}{ Social Democratic Vote } & \multicolumn{4}{|c|}{ Electoral Relevance } \\
\hline & Outsider & Insider & Outsider & Insider & National & Outsider & Insider & National & Outsider & Insider & diff & ratio \\
\hline \multicolumn{13}{|l|}{ Nordic } \\
\hline Denmark & $12.9 \%$ & $44.0 \%$ & $90.0 \%$ & $94.9 \%$ & $93.5 \%$ & $26.1 \%$ & $26.9 \%$ & $27.1 \%$ & $11.9 \%$ & $44.3 \%$ & 32.4 & 3.7 \\
\hline Finland & $14.0 \%$ & $33.8 \%$ & $74.4 \%$ & $82.3 \%$ & $82.9 \%$ & $19.2 \%$ & $22.1 \%$ & $22.2 \%$ & $10.9 \%$ & $33.4 \%$ & 22.5 & 3.1 \\
\hline Sweden & $18.8 \%$ & $40.2 \%$ & $88.3 \%$ & $92.8 \%$ & $91.1 \%$ & $34.5 \%$ & $34.6 \%$ & $33.1 \%$ & $19.0 \%$ & $42.7 \%$ & 23.8 & 2.3 \\
\hline \multirow[t]{2}{*}{ Norway } & $12.6 \%$ & $46.3 \%$ & $81.6 \%$ & $88.0 \%$ & $86.9 \%$ & $31.2 \%$ & $33.4 \%$ & $33.0 \%$ & $11.2 \%$ & $47.5 \%$ & 36.3 & 4.3 \\
\hline & $14.6 \%$ & $41.1 \%$ & $83.6 \%$ & $89.5 \%$ & $88.6 \%$ & $27.7 \%$ & $29.3 \%$ & $28.9 \%$ & $13.2 \%$ & $42.0 \%$ & 28.7 & 3.3 \\
\hline \multicolumn{13}{|l|}{ Liberal } \\
\hline United Kindgom & $14.0 \%$ & $34.0 \%$ & $68.1 \%$ & $70.2 \%$ & $72.4 \%$ & $40.4 \%$ & $41.4 \%$ & $39.9 \%$ & $13.4 \%$ & $34.2 \%$ & 20.8 & 2.6 \\
\hline \multirow[t]{2}{*}{ Ireland } & $20.8 \%$ & $25.8 \%$ & $71.5 \%$ & $80.9 \%$ & $77.9 \%$ & $12.3 \%$ & $11.2 \%$ & $11.0 \%$ & $21.4 \%$ & $27.3 \%$ & 5.9 & 1.3 \\
\hline & $17.4 \%$ & $29.9 \%$ & $69.8 \%$ & $75.6 \%$ & $75.2 \%$ & $26.4 \%$ & $26.3 \%$ & $25.4 \%$ & $17.4 \%$ & $30.7 \%$ & 13.3 & 1.9 \\
\hline \multicolumn{13}{|l|}{ Continental } \\
\hline Belgium & $21.5 \%$ & $30.0 \%$ & $92.4 \%$ & $94.9 \%$ & $92.6 \%$ & $30.0 \%$ & $24.4 \%$ & $25.4 \%$ & $25.3 \%$ & $29.6 \%$ & 4.2 & 1.2 \\
\hline Germany & $23.6 \%$ & $29.8 \%$ & $76.7 \%$ & $84.4 \%$ & $82.5 \%$ & $32.4 \%$ & $32.8 \%$ & $32.0 \%$ & $22.2 \%$ & $31.2 \%$ & 9.1 & 1.4 \\
\hline France & $19.8 \%$ & $32.9 \%$ & $62.3 \%$ & $72.8 \%$ & $73.9 \%$ & $34.4 \%$ & $33.1 \%$ & $33.0 \%$ & $17.4 \%$ & $32.6 \%$ & 15.2 & 1.9 \\
\hline Netherlands & $27.2 \%$ & $27.3 \%$ & $82.0 \%$ & $84.7 \%$ & $84.6 \%$ & $20.9 \%$ & $20.8 \%$ & $20.6 \%$ & $26.8 \%$ & $27.7 \%$ & 0.9 & 1.0 \\
\hline Switzerland & $21.9 \%$ & $31.6 \%$ & $66.9 \%$ & $65.1 \%$ & $69.5 \%$ & $22.5 \%$ & $23.3 \%$ & $22.1 \%$ & $21.5 \%$ & $31.3 \%$ & 9.8 & 1.5 \\
\hline \multirow[t]{2}{*}{ Austria } & $17.8 \%$ & $33.4 \%$ & $82.0 \%$ & $84.2 \%$ & $84.9 \%$ & $30.2 \%$ & $33.2 \%$ & $33.0 \%$ & $15.7 \%$ & $33.3 \%$ & 17.5 & 2.1 \\
\hline & $21.9 \%$ & $30.8 \%$ & $77.0 \%$ & $81.0 \%$ & $81.3 \%$ & $28.4 \%$ & $27.9 \%$ & $27.7 \%$ & $21.5 \%$ & $30.9 \%$ & 9.5 & 1.5 \\
\hline \multicolumn{13}{|l|}{ Southern } \\
\hline Spain & $30.1 \%$ & $24.9 \%$ & $78.3 \%$ & $83.8 \%$ & $82.4 \%$ & $45.9 \%$ & $39.5 \%$ & $40.5 \%$ & $32.4 \%$ & $24.7 \%$ & -7.7 & 0.8 \\
\hline Italy & $18.6 \%$ & $24.9 \%$ & $81.7 \%$ & $87.7 \%$ & $84.2 \%$ & $32.7 \%$ & $31.6 \%$ & $31.9 \%$ & $18.5 \%$ & $25.6 \%$ & 7.2 & 1.4 \\
\hline Portugal & $20.8 \%$ & $29.9 \%$ & $64.4 \%$ & $77.2 \%$ & $74.0 \%$ & $41.6 \%$ & $38.4 \%$ & $39.9 \%$ & $18.9 \%$ & $30.1 \%$ & 11.2 & 1.6 \\
\hline \multirow[t]{2}{*}{ Greece } & $19.5 \%$ & $21.8 \%$ & $88.2 \%$ & $90.0 \%$ & $89.8 \%$ & $42.8 \%$ & $42.1 \%$ & $42.9 \%$ & $19.1 \%$ & $21.4 \%$ & 2.3 & 1.1 \\
\hline & $22.2 \%$ & $25.4 \%$ & $78.1 \%$ & $84.7 \%$ & $82.6 \%$ & $40.7 \%$ & $37.9 \%$ & $38.8 \%$ & $22.2 \%$ & $25.5 \%$ & 3.2 & 1.2 \\
\hline \multicolumn{13}{|l|}{ Visegrad } \\
\hline Czech Republic & $13.6 \%$ & $36.1 \%$ & $56.6 \%$ & $64.6 \%$ & $60.9 \%$ & $31.6 \%$ & $32.5 \%$ & $32.3 \%$ & $12.3 \%$ & $38.6 \%$ & 26.2 & 3.1 \\
\hline Hungary & $13.5 \%$ & $34.0 \%$ & $71.4 \%$ & $78.5 \%$ & $75.9 \%$ & $27.9 \%$ & $27.5 \%$ & $30.6 \%$ & $11.6 \%$ & $31.7 \%$ & 20.1 & 2.7 \\
\hline \multirow[t]{2}{*}{ Poland } & $22.7 \%$ & $24.0 \%$ & $64.6 \%$ & $70.1 \%$ & $70.0 \%$ & $16.0 \%$ & $16.6 \%$ & $17.0 \%$ & $19.7 \%$ & $23.6 \%$ & 38.0 & 1.2 \\
\hline & $16.6 \%$ & $31.4 \%$ & $64.2 \%$ & $71.1 \%$ & $69.0 \%$ & $25.2 \%$ & $25.5 \%$ & $26.6 \%$ & $14.5 \%$ & $31.3 \%$ & 16.7 & 2.4 \\
\hline
\end{tabular}

Note: Relative groups shares are based on all pooled EU-SILC (2002-2015). Participation and social democratic vote shares are predicted probabilities based on unconditional country-by-country logistic regressions of all pooled ESS Rounds 1-8 (2002-2016). 


\section{Supplementary Information 1: Labor Market Policy Dataset}

\section{Coverage}

Countries and time period: Austria, Belgium, France, Italy, Germany, Greece, Netherlands, Portugal, and Spain; 2000-2016.

Policies: passive labor market policy (PLMP), active labor market policy (ALMP), employment protection legislation (EPL), early retirement (ER) and short-time work (STW).

\section{Data Collection}

This dataset collected reforms implemented on the national level. The data collection proceeded in several steps to ensure all the relevant policy reforms in the fields of labor market and family policy reforms were gathered. In a first step, we collected all the information on policy changes from the ILO's NATLEX and TRAVAIL databases. Then we compared these changes with the EU's MISSOC database and the EUR-Lex database. In a second step, we used the already existing LABREF database (2000-2016) and the Fondazione Rodolfo DeBenedetti's Social Reform Database (1980-2007) to check for potentially missing labor market reforms. Already at this stage, there were only a few reforms that were not already collected in the first stage. In a last step, we cross-checked the collected data with countryspecific secondary literature that describes the relevant reforms. Taken together, these three steps assure that there no labor market reforms was missed. Table SI1.1 shows the number of absolute and relative number policy changes by country and policy fields (ALMP, PLMP, EPL, ER, STW).

\section{Coding of the Policy Changes}

The unit of analysis is a single reform: a collection of policy measures (policy changes), which have been formally ratified in one document. Projected and rejected reform projects are not part of the dataset. Multidimensional reform packages that affect more than just one labor market institution (e.g. ALMP and PLMP) are coded separately for each institution affected by the reform. Based on the detailed policy content collected, we then code each policy change with respect to its distributional impact on labor market insiders and labor market outsiders $(+1,0$, or -1$)$. In addition, each policy measure is weighted by 1 if it is a comprehensive reform that addresses the broader design of existing systems or by 0.5 if it 
Table SI1.1: Number of Policy Changes by Country and Policy Instrument (2000-2016), abs. and rel.

\begin{tabular}{l|lllll|l}
\hline \hline country & ALMP & PLMP & EPL & ER & STW & Total \\
\hline Austria & 39 & 22 & 25 & 10 & 11 & 107 \\
\multirow{3}{*}{ Belgium } & 36.45 & 20.56 & 23.36 & 9.35 & 10.28 & 100 \\
& 70 & 25 & 22 & 8 & 7 & 132 \\
Germany & 53.03 & 18.94 & 16.67 & 6.06 & 5.3 & 100 \\
Spain & 33 & 19 & 26 & 2 & 8 & 88 \\
& 37.5 & 21.59 & 29.55 & 2.27 & 9.09 & 100 \\
France & 43 & 33 & 39 & 9 & 4 & 128 \\
& 33.59 & 25.78 & 30.47 & 7.03 & 3.12 & 100 \\
Greece & 59 & 22 & 48 & 13 & 8 & 150 \\
& 39.33 & 14.67 & 32 & 8.67 & 5.33 & 100 \\
Italy & 33 & 16 & 42 & 0 & 4 & 95 \\
\multirow{4}{*}{ Netherlands } & 34.74 & 16.84 & 44.21 & 0 & 4.21 & 100 \\
& 44 & 32 & 62 & 3 & 6 & 147 \\
Portugal & 29.93 & 21.77 & 42.18 & 2.04 & 4.08 & 100 \\
& 37 & 16 & 28 & 2 & 4 & 87 \\
& 42.53 & 18.39 & 32.18 & 2.3 & 4.6 & 100 \\
\hline Total & 49 & 30 & 23 & 7 & 2 & 111 \\
& 44.14 & 27.03 & 20.72 & 6.31 & 1.8 & 100 \\
\hline \hline
\end{tabular}

is a marginal change. We do not code the reforms in terms of whether outsiders or insiders prefer these policies. The focus lies exclusively to what extent policy changes directly affect the labor market situation of insiders and outsiders. It is not about to what extent insiders and outsiders actually differ in their preferences over these policies. In what follows, we describe for each policy field how the reforms/policy changes were coded.

Employment Protection Legislation: Here we distinguish between standard (insider) and atypical work (outsider) contracts. Rigid employment protection legislation for standard employment contracts privileges insiders. Outsiders, on the other hand, are penalized since their chance to enter standard employment decreases. Labor market reforms that only improve EPL for the standard employed lead to a further dualization of the labor market. Conversely, increasing EPL for atypical employment contracts (e.g. part-time or fixed-term contracts) improves the situation of outsiders.

Passive Labor Market Policy: The distributional effects of passive labor market policies (PLMPs) are more ambiguous. Rueda (2005) argues that PLMPs focus on the financial support of the unemployed and are therefore pro-outsider policies. But there is a caveat: 
outsiders in social insurance welfare regimes (most Continental and Southern Europe) often do not have sufficient social rights to access these schemes due to their atypical work biographies. Thus, eligibility conditions are of particular importance. For example, if policy changes extend the eligibility conditions to fixed- term contracts, then the reform improves the situation of outsiders. But PLMPs can also be manipulated to further exclude outsiders and favor insiders, for example, by limiting the eligibility criteria to access PLMPs.

Active Labor Market Policy: There is a whole variety of Active labor market policies (ALMPs). Rueda describes all ALMPs as "unambiguously pro-outsider" (2007, p. 73). Although all types of ALMPs have in common that they aim at outsiders, not all of them can be classified as pro-outsider policies. In particular, the measures of incentive reinforcement (increasing conditionality between passive and active benefits, use of sanctions) often do not improve the situation of outsiders but sanction them and force them to take any job offer they get independent from whether it matches their skills and preferences (Bonoli, 2013). All other ALMP types (employment assistance, upskilling, occupation) are pro-outsider.

Short-Time Work: Short-time work (STW) programs permit firms in times of crisis to temporarily curb the working hours of full-time jobs without firing the employed. However, not all workers benefit from these measures. Insiders usually benefit strongly from STW programs as they keep their jobs, whereas outsiders are usually dismissed.

Early Retirement: Early retirement (ER) reforms aim at easing withdrawal from work. ER reforms do not have clear-cut distributional effects. If ER is only granted to people with a standard work biography who paid their social contributions for some $30 / 40$ years, then ER clearly favors insiders over outsiders. But if eligibility criteria to access ER programs are widened to include atypical employees, then the change is pro-outsider.

\section{Advantages and Disadvantages of the Measure}

The advantages of such a measure are manifold. First, we try to clearly distinguish whether a policy change improves/worsens the situation of insiders or/and outsiders. Second, coding the actual policy output and not just looking at aggregate outcome variables such as social spending can minimize the potential of confounding factors. Third, it allows us not only to identify descriptive trends over time and across country, but to tie certain policy outputs to 
specific parties. By looking only at spending or other outcome data this is rarely possible. It can be at times difficult to attribute certain spending outcomes to policies that usually take a while to become visible in the outcome variable. Big reforms become only visible in the budget years later and the incoming government can reap the benefits of reforms implemented before they even took office. In order to avoid linking outcomes to the "wrong" government, this measure can link policy output directly to the party in office.

There are also some concerns that can be leveled against this measure. One might raise the question to what extent subjective assessment of how a given reform impact on the three dimensions of consumption, investment and regulation is involved. Even though we have coded all these reforms ourselves, a pre-test was designed to test the subjectivity of coding decisions. Four persons were assigned to code the same 20 reforms and then agreement scores were calculated. The results suggest that different coders evaluated the reforms in a very similar way. In addition, the results of measure were always compared to the relevant country-specific literature. A second drawback of this measure is that it implicitly assumes that most policy changes have similar magnitude. Every policy change can only be coded into one of five categories from -1 to +1 (direction $\mathrm{X}$ scope). As a consequence, this measure should only be interpreted as an ordinal approximation to the actual effect. 


\section{Supplementary Information 2: Additional Figures and Tables}

Table SI2.1: Share of outsiders among the middle classes, manual workers, and routine workers

\begin{tabular}{llll}
\hline \hline Nordic & Middle classes & Manual workers & Routine workers \\
Denmark & $16.3 \%$ & $6.7 \%$ & \\
Finland & $15.2 \%$ & $12.6 \%$ & $23.9 \%$ \\
Sweden & $23.6 \%$ & $11.6 \%$ & $29.8 \%$ \\
Norway & $16.7 \%$ & $7.2 \%$ & $37.4 \%$ \\
& $\underline{18.0 \%}$ & $\underline{9.5 \%}$ & $27.9 \%$ \\
& &
\end{tabular}

\section{Liberal}

United Kingdom $\quad 15.7 \%$

Ireland

\section{Continental}

Austria

Belgium

Switzerland

Germany

France

Netherlands

\begin{tabular}{ll}
$21.6 \%$ & $11.6 \%$ \\
$23.8 \%$ & $19.4 \%$ \\
$25.2 \%$ & $17.0 \%$ \\
$24.7 \%$ & $20.5 \%$ \\
$21.0 \%$ & $17.2 \%$ \\
$36.2 \%$ & $18.3 \%$ \\
$25.4 \%$ & $17.3 \%$ \\
\hline
\end{tabular}

\begin{tabular}{l}
$35.4 \%$ \\
$49.7 \%$ \\
$33.7 \%$ \\
$43.5 \%$ \\
$37.7 \%$ \\
$39.5 \%$ \\
$39.9 \%$ \\
\hline
\end{tabular}

Southern

Spain

Greece

Italy

Portugal

\begin{tabular}{lll}
$29.9 \%$ & $35.2 \%$ & $52.2 \%$ \\
$22.3 \%$ & $18.2 \%$ & $50.9 \%$ \\
$19.9 \%$ & $18.8 \%$ & $30.8 \%$ \\
$20.6 \%$ & $21.3 \%$ & $31.7 \%$ \\
$23.2 \%$ & $\underline{23.4 \%}$ & $\underline{41.4 \%}$ \\
\hline
\end{tabular}

\section{Visegrad}

Hungary

Poland

$10.5 \%$

$24.3 \%$

$13.2 \%$

$16.0 \%$

\begin{tabular}{l}
$16.7 \%$ \\
$22.9 \%$ \\
$12.3 \%$ \\
$17.3 \%$ \\
\hline
\end{tabular}

$23.5 \%$

$35.6 \%$

$30.9 \%$

$30.0 \%$

Total Mean

$21.1 \%$

$16.9 \%$

$35.3 \%$

Note: The three occupational groups are based on Oesch's 16-class scheme operationalized by ISCO 2-digit codes and re-categorized relying on replication files provided by Jane Gingrich. The displayed numbers are labor market outsiders as a share of total population averaged across all years available in EU-SILC (2004-2015). 
Table SI2.2: Number of Observations of ESS Rounds 1-8, by Country

\begin{tabular}{lrrrrrrrr|r}
\hline \hline Country & ESS1 & ESS2 & ESS3 & ESS4 & ESS5 & ESS6 & ESS7 & ESS8 & Total \\
\hline Austria & 2,228 & 2,164 & 2,298 & 0 & 0 & 0 & 1,762 & 1,994 & 10,446 \\
Belgium & 1,810 & 1,697 & 1,709 & 1,682 & 1,639 & 1,790 & 1,686 & 1,702 & 13,715 \\
Switzerland & 1,973 & 2,089 & 1,765 & 1,776 & 1,449 & 1,439 & 1,476 & 1,464 & 13,432 \\
Czech Republic & 1,343 & 2,934 & 0 & 1,955 & 2,324 & 1,941 & 2,082 & 2,186 & 14,765 \\
Germany & 2,812 & 2,742 & 2,829 & 2,691 & 2,898 & 2,832 & 2,938 & 2,726 & 22,468 \\
Denmark & 1,466 & 1,429 & 1,472 & 1,550 & 1,509 & 1,582 & 1,435 & 0 & 10,443 \\
Spain & 1,670 & 1,608 & 1,814 & 2,486 & 1,840 & 1,841 & 1,880 & 1,918 & 15,057 \\
Finland & 1,891 & 1,924 & 1,815 & 2,105 & 1,794 & 2,116 & 2,022 & 1,868 & 15,535 \\
France & 1,477 & 1,769 & 1,934 & 2,009 & 1,680 & 1,927 & 1,858 & 2,016 & 14,670 \\
Great Britain & 2,000 & 1,841 & 2,323 & 2,301 & 2,365 & 2,241 & 2,227 & 1,925 & 17,223 \\
Greece & 2,511 & 2,363 & 0 & 2,019 & 2,649 & 0 & 0 & 0 & 9,542 \\
Hungary & 1,610 & 1,430 & 1,489 & 1,506 & 1,535 & 1,962 & 1,663 & 1,580 & 12,775 \\
Ireland & 1,995 & 2,236 & 1,750 & 1,723 & 2,507 & 2,581 & 2,343 & 2,729 & 17,864 \\
Italy & 1,193 & 1,497 & 0 & 0 & 0 & 935 & 0 & 2,524 & 6,149 \\
Netherlands & 2,305 & 1,839 & 1,854 & 1,740 & 1,793 & 1,812 & 1,866 & 1,644 & 14,853 \\
Norway & 2,008 & 1,694 & 1,669 & 1,482 & 1,476 & 1,547 & 1,365 & 1,479 & 12,720 \\
Poland & 1,971 & 1,614 & 1,624 & 1,547 & 1,659 & 1,822 & 1,569 & 1,632 & 13,438 \\
Portugal & 1,444 & 2,008 & 2,180 & 2,296 & 2,104 & 2,117 & 1,227 & 1,249 & 14,625 \\
Sweden & 1,911 & 1,861 & 1,854 & 1,745 & 1,437 & 1,780 & 1,736 & 1,515 & 13,839 \\
\hline Total & 35,618 & 36,739 & 30,379 & 32,613 & 32,658 & 32,265 & 31,135 & 32,152 & 263,559 \\
\hline \hline
\end{tabular}




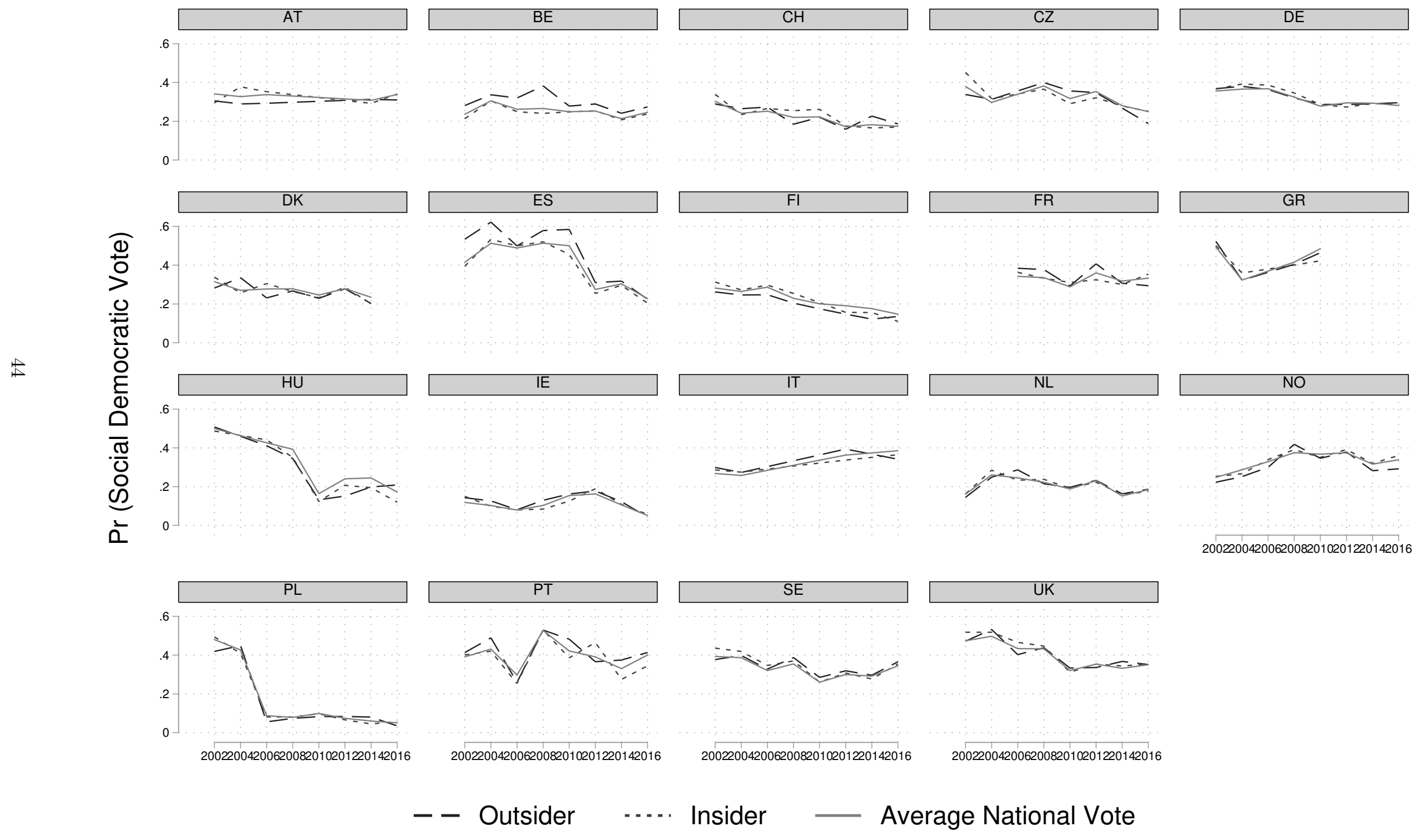

Figure SI2.1: Probability to Vote for Social Democratic Party by Insider and Outsider compared to the National Average Social Democratic Vote Share 
Table SI2.3: Electoral Relevance of Insiders and Outsiders for Social Democrats, pooled years 2002-2016 (conditional models)

\begin{tabular}{|c|c|c|c|c|c|c|c|c|c|c|c|}
\hline & \multicolumn{2}{|c|}{ Group Share } & \multicolumn{3}{|c|}{ Turnout } & \multicolumn{3}{|c|}{ Social Democratic Vote } & \multicolumn{3}{|c|}{ Electoral Relevance } \\
\hline & Outsider & Insider & Outsider & Insider & National & Outsider & Insider & National & Outsider & Insider & diff \\
\hline \multicolumn{12}{|l|}{ Nordic } \\
\hline Denmark & $12.9 \%$ & $44.0 \%$ & $93.9 \%$ & $94.4 \%$ & $93.5 \%$ & $26.0 \%$ & $29.3 \%$ & $27.1 \%$ & $12.3 \%$ & $47.9 \%$ & 35.5 \\
\hline Finland & $14.0 \%$ & $33.8 \%$ & $81.4 \%$ & $81.7 \%$ & $82.9 \%$ & $21.3 \%$ & $24.1 \%$ & $22.2 \%$ & $13.2 \%$ & $36.1 \%$ & 22.9 \\
\hline Sweden & $18.8 \%$ & $40.2 \%$ & $92.2 \%$ & $92.3 \%$ & $91.1 \%$ & $34.2 \%$ & $35.8 \%$ & $33.2 \%$ & $19.7 \%$ & $44.0 \%$ & 24.3 \\
\hline Norway & $12.6 \%$ & $46.3 \%$ & $86.3 \%$ & $88.0 \%$ & $86.9 \%$ & $31.2 \%$ & $34.7 \%$ & $33.0 \%$ & $11.8 \%$ & $49.3 \%$ & 37.5 \\
\hline & $14.6 \%$ & $41.1 \%$ & $88.4 \%$ & $89.1 \%$ & $88.6 \%$ & $28.2 \%$ & $31.0 \%$ & $28.9 \%$ & $14.3 \%$ & $44.3 \%$ & 30.1 \\
\hline \multicolumn{12}{|l|}{ Liberal } \\
\hline United Kindgom & $14.0 \%$ & $34.0 \%$ & $73.3 \%$ & $72.6 \%$ & $72.4 \%$ & $38.2 \%$ & $41.1 \%$ & $39.9 \%$ & $13.6 \%$ & $35.1 \%$ & 21.5 \\
\hline Ireland & $20.8 \%$ & $25.8 \%$ & $78.4 \%$ & $82.0 \%$ & $77.9 \%$ & $10.9 \%$ & $9.9 \%$ & $11.0 \%$ & $20.7 \%$ & $24.6 \%$ & 3.9 \\
\hline & $17.4 \%$ & $29.9 \%$ & $75.9 \%$ & $77.3 \%$ & $75.1 \%$ & $24.6 \%$ & $25.5 \%$ & $25.5 \%$ & $17.2 \%$ & $29.8 \%$ & 12.7 \\
\hline \multicolumn{12}{|l|}{ Continental } \\
\hline Belgium & $21.5 \%$ & $30.0 \%$ & $92.4 \%$ & $93.8 \%$ & $92.6 \%$ & $28.6 \%$ & $25.2 \%$ & $25.4 \%$ & $24.2 \%$ & $30.2 \%$ & 6.0 \\
\hline Germany & $23.6 \%$ & $29.8 \%$ & $81.3 \%$ & $83.6 \%$ & $82.5 \%$ & $33.7 \%$ & $34.6 \%$ & $32.0 \%$ & $24.5 \%$ & $32.6 \%$ & 8.1 \\
\hline France & $19.8 \%$ & $32.9 \%$ & $72.4 \%$ & $75.5 \%$ & $73.9 \%$ & $35.6 \%$ & $33.1 \%$ & $33.0 \%$ & $20.9 \%$ & $33.8 \%$ & 12.8 \\
\hline Netherlands & $27.2 \%$ & $27.3 \%$ & $85.8 \%$ & $85.7 \%$ & $84.6 \%$ & $20.4 \%$ & $21.3 \%$ & $20.6 \%$ & $27.3 \%$ & $28.6 \%$ & 1.3 \\
\hline Switzerland & $21.9 \%$ & $31.6 \%$ & $72.5 \%$ & $68.9 \%$ & $69.5 \%$ & $23.0 \%$ & $23.6 \%$ & $22.1 \%$ & $23.7 \%$ & $33.5 \%$ & 9.8 \\
\hline \multirow{2}{*}{ Austria } & $17.8 \%$ & $33.4 \%$ & $86.6 \%$ & $85.4 \%$ & $84.9 \%$ & $32.1 \%$ & $37.4 \%$ & $33.0 \%$ & $17.7 \%$ & $38.1 \%$ & 20.4 \\
\hline & $21.9 \%$ & $30.8 \%$ & $81.8 \%$ & $82.2 \%$ & $81.3 \%$ & $28.9 \%$ & $29.2 \%$ & $27.7 \%$ & $23.1 \%$ & $32.8 \%$ & 9.7 \\
\hline \multicolumn{12}{|l|}{ Southern } \\
\hline Spain & $30.1 \%$ & $24.9 \%$ & $82.5 \%$ & $83.2 \%$ & $82.4 \%$ & $45.2 \%$ & $41.4 \%$ & $40.5 \%$ & $33.6 \%$ & $25.8 \%$ & -7.9 \\
\hline Italy & $18.6 \%$ & $24.9 \%$ & $87.9 \%$ & $88.3 \%$ & $84.2 \%$ & $39.2 \%$ & $33.2 \%$ & $31.8 \%$ & $23.8 \%$ & $27.2 \%$ & 3.3 \\
\hline Portugal & $20.8 \%$ & $29.9 \%$ & $69.3 \%$ & $78.3 \%$ & $74.0 \%$ & $44.3 \%$ & $40.4 \%$ & $39.9 \%$ & $21.7 \%$ & $32.1 \%$ & 10.5 \\
\hline \multirow[t]{2}{*}{ Greece } & $19.5 \%$ & $21.8 \%$ & $90.4 \%$ & $91.4 \%$ & $89.8 \%$ & $41.6 \%$ & $43.0 \%$ & $42.9 \%$ & $19.1 \%$ & $22.2 \%$ & 3.2 \\
\hline & $22.2 \%$ & $25.4 \%$ & $82.5 \%$ & $85.3 \%$ & $82.6 \%$ & $42.6 \%$ & $39.5 \%$ & $38.8 \%$ & $24.5 \%$ & $26.8 \%$ & 2.3 \\
\hline \multicolumn{12}{|l|}{ Visegrad } \\
\hline Czech Republic & $13.6 \%$ & $36.1 \%$ & $57.8 \%$ & $63.0 \%$ & $60.9 \%$ & $31.4 \%$ & $36.4 \%$ & $32.3 \%$ & $12.5 \%$ & $42.2 \%$ & 29.7 \\
\hline Hungary & $13.5 \%$ & $34.0 \%$ & $76.4 \%$ & $78.5 \%$ & $75.9 \%$ & $31.8 \%$ & $31.3 \%$ & $30.6 \%$ & $14.1 \%$ & $36.0 \%$ & 21.9 \\
\hline \multirow[t]{2}{*}{ Poland } & $22.7 \%$ & $24.0 \%$ & $70.1 \%$ & $71.7 \%$ & $70.0 \%$ & $17.0 \%$ & $17.5 \%$ & $17.0 \%$ & $22.7 \%$ & $25.3 \%$ & 2.5 \\
\hline & $\underline{16.6 \%}$ & $31.4 \%$ & $\underline{68.1 \%}$ & $71.1 \%$ & $\underline{69.0 \%}$ & $26.7 \%$ & $28.4 \%$ & $26.6 \%$ & $16.4 \%$ & $34.5 \%$ & 18.0 \\
\hline
\end{tabular}

Note: Relative groups shares are based on EU-SILC (2002-2015). Participation and social democratic vote shares are predicted probabilities based on country-by-country logistic regressions of ESS Rounds 1-8 (2002-2016) including control variables (sex, age, education, household income, religiosity, union membership). Unconditional predicted probabilities (without controls) yield largely the same results - only difference is a slightly bigger participation gap. 

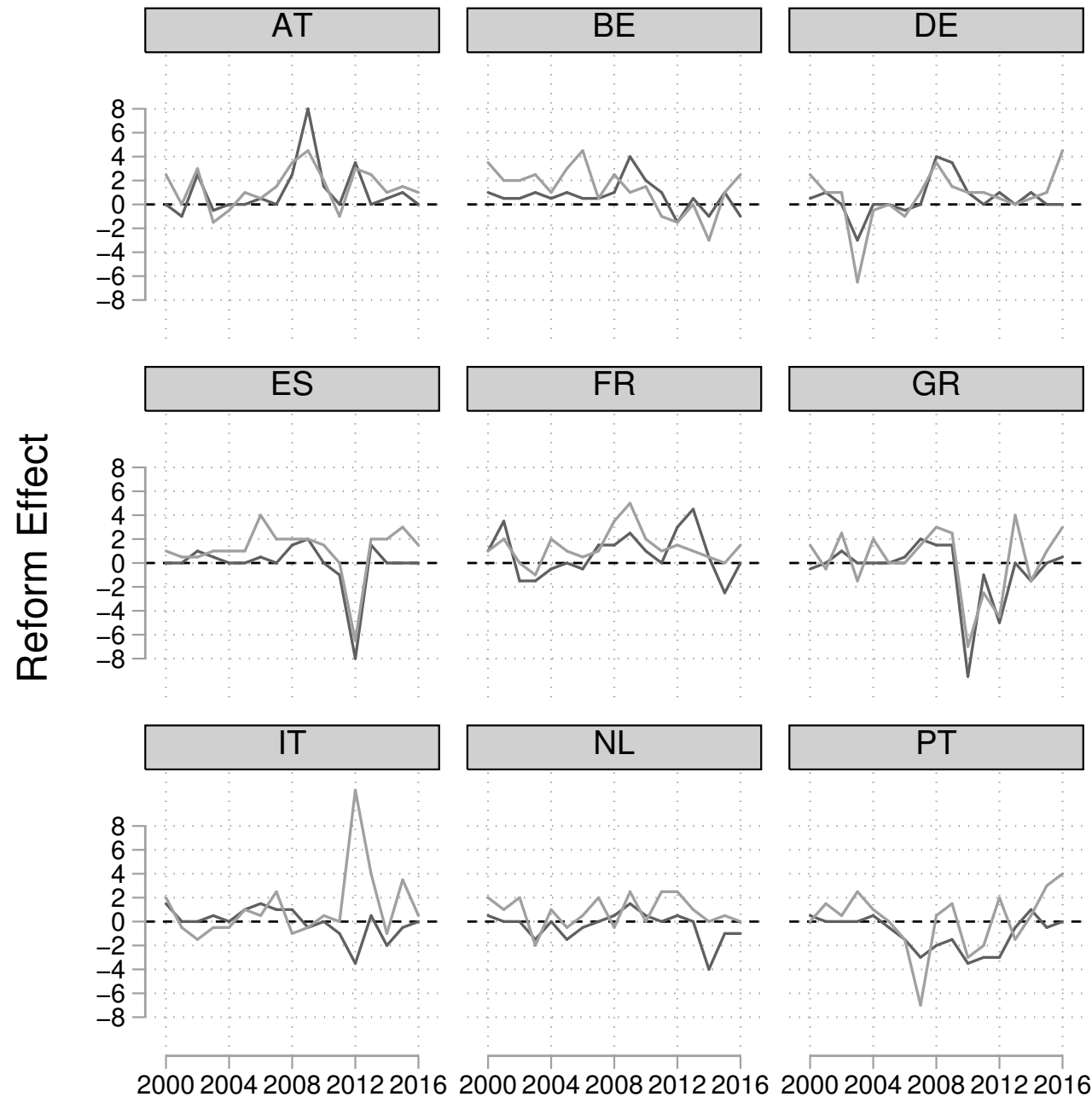

Insider

Outsider

Figure SI2.2: Effects of all labor market reforms on insiders and outsiders, by country, 2000-2016 (Source: own data, see appendix) 


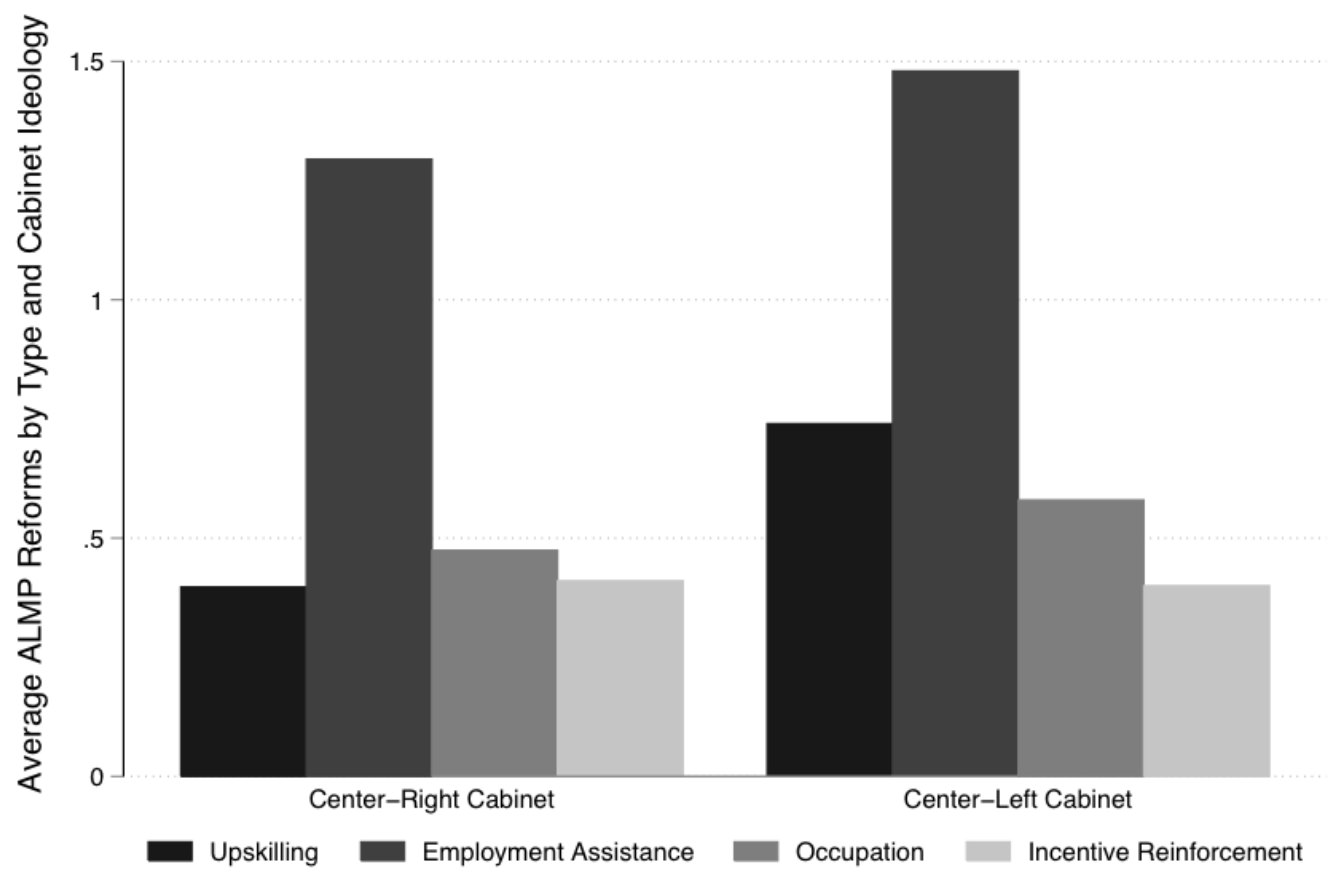

Figure SI2.3: Average reform direction by ALMP type and cabinet ideology (source: own data, see appendix) 


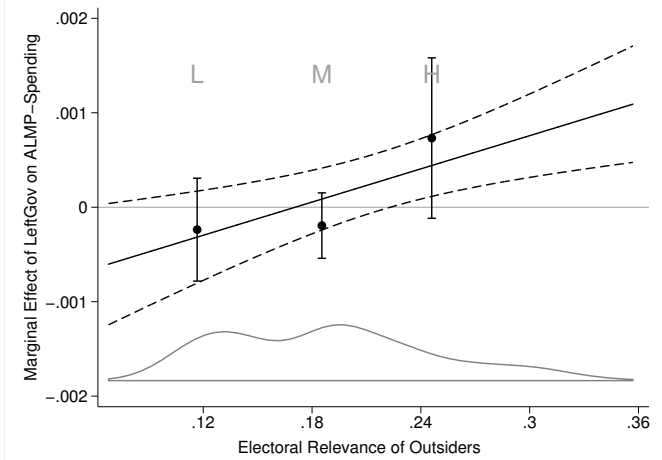

(a) ALMP, Binning Estimator

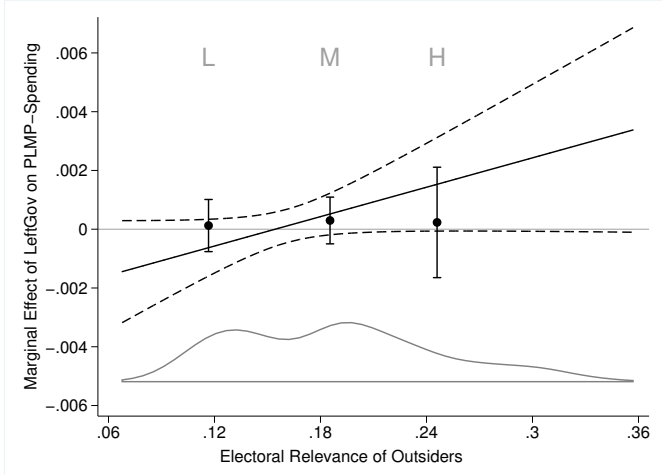

(c) PLMP, Binning Estimator

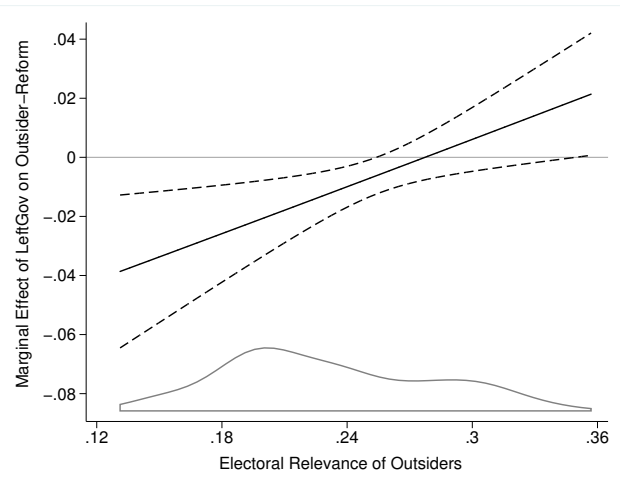

(e) Outsider-Reform, Kernel Estimator

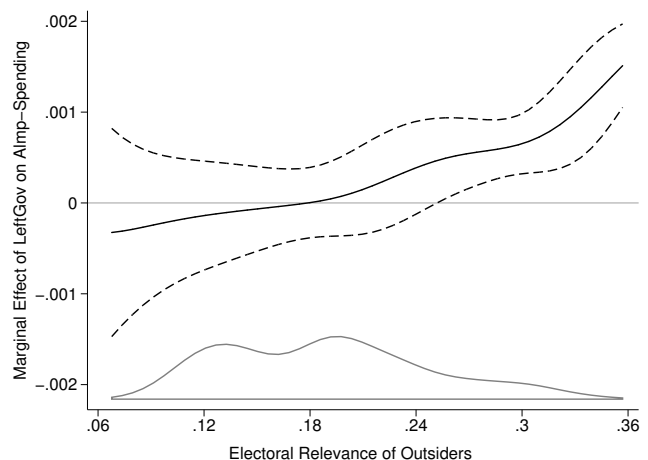

(b) ALMP, Kernel Estimator

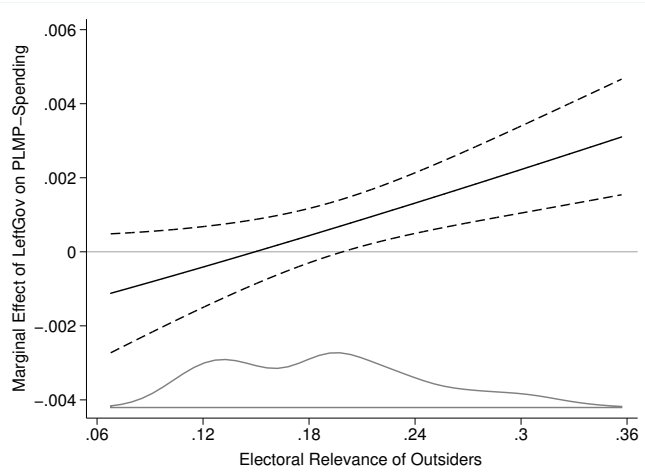

(d) PLMP, Kernel Estimator

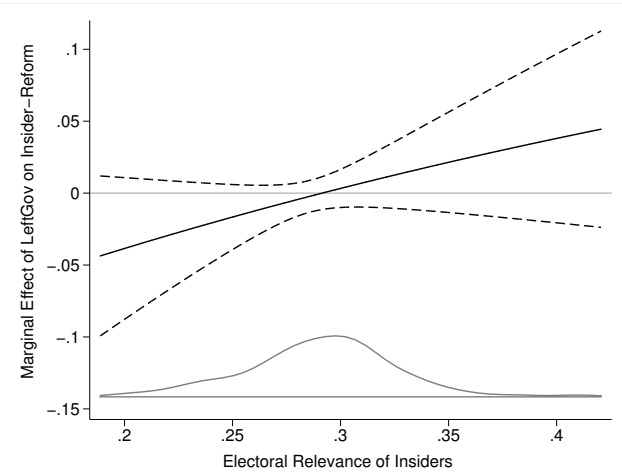

(f) Insider-Reform, Kernel Estimator

Figure SI2.4: Tests for Non-Linearity of Interaction Effects

Notes: Binning estimator not possible to estimate for the reform data due to the low sample size. 

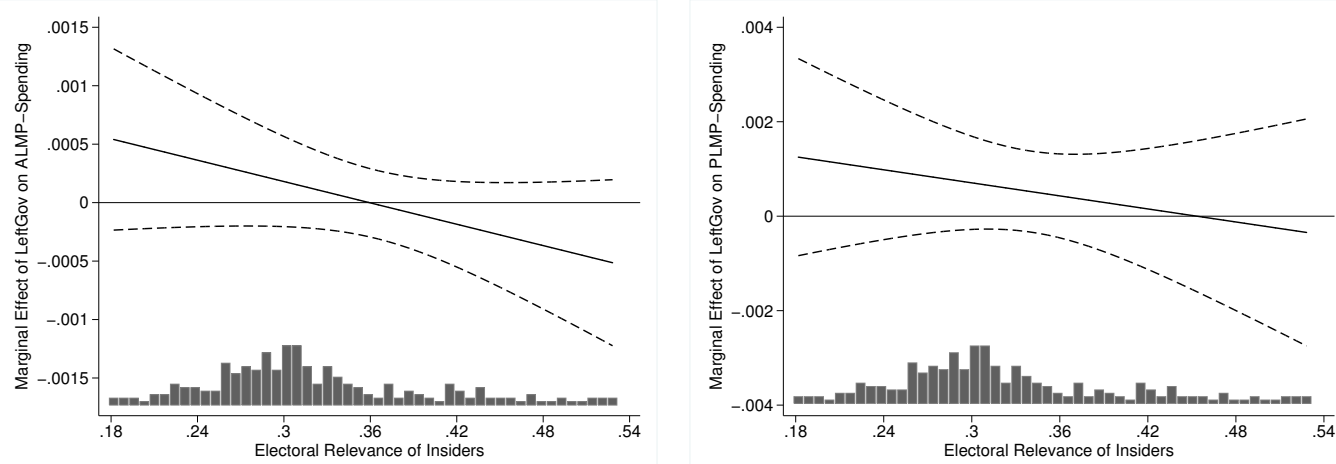

Figure SI2.5: Interaction LeftGov with electoral relevance of insiders on ALMP and PLMP spending with $95 \%$-confidence intervals (based on Model 4 and 8 in Table 2). Histograms show the distribution of the electoral relevance of insiders.

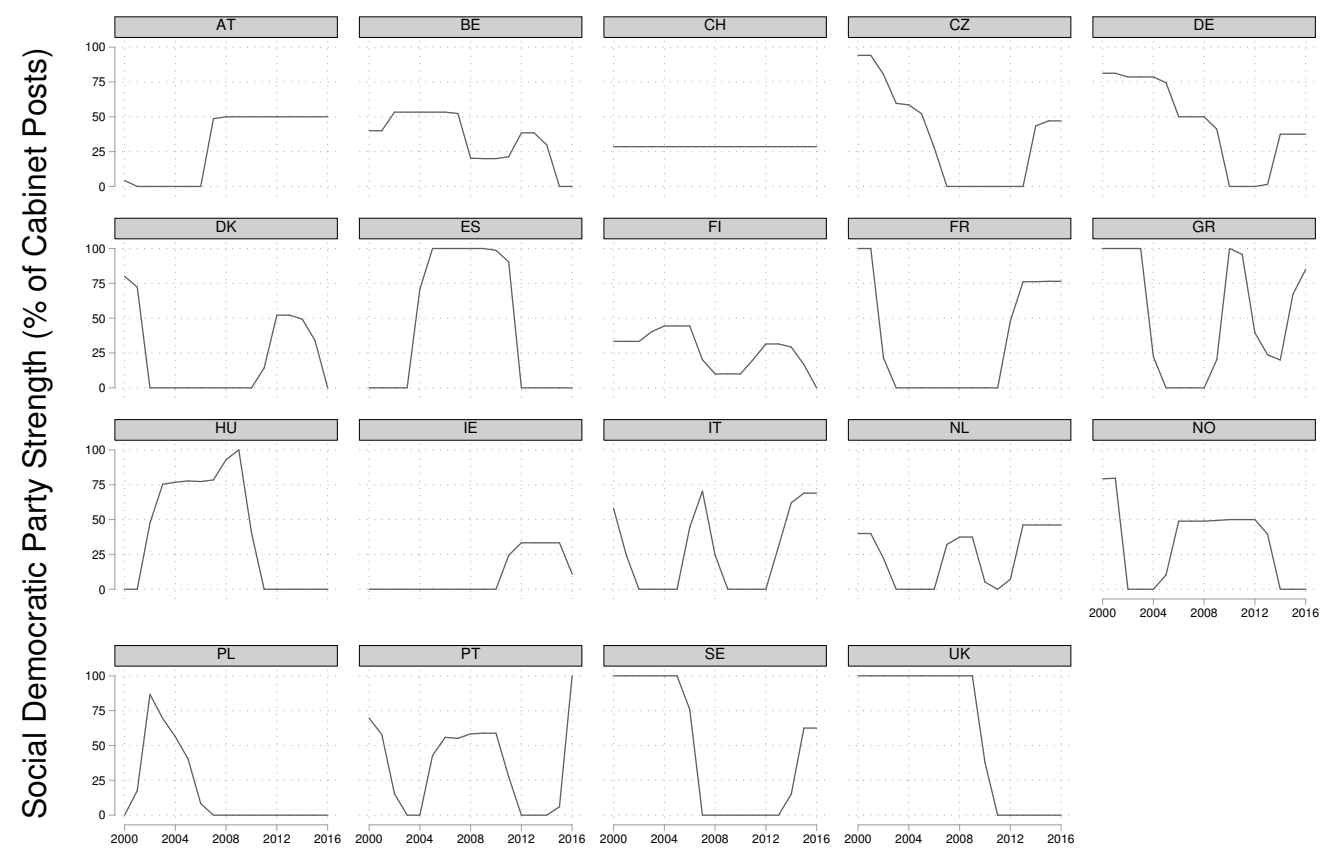

Figure SI2.6: Strength of social democratic parties measured by the share of cabinet posts (Source: Armingeon et al. 2018, adjusted to only include the main social democratic party of each country) 


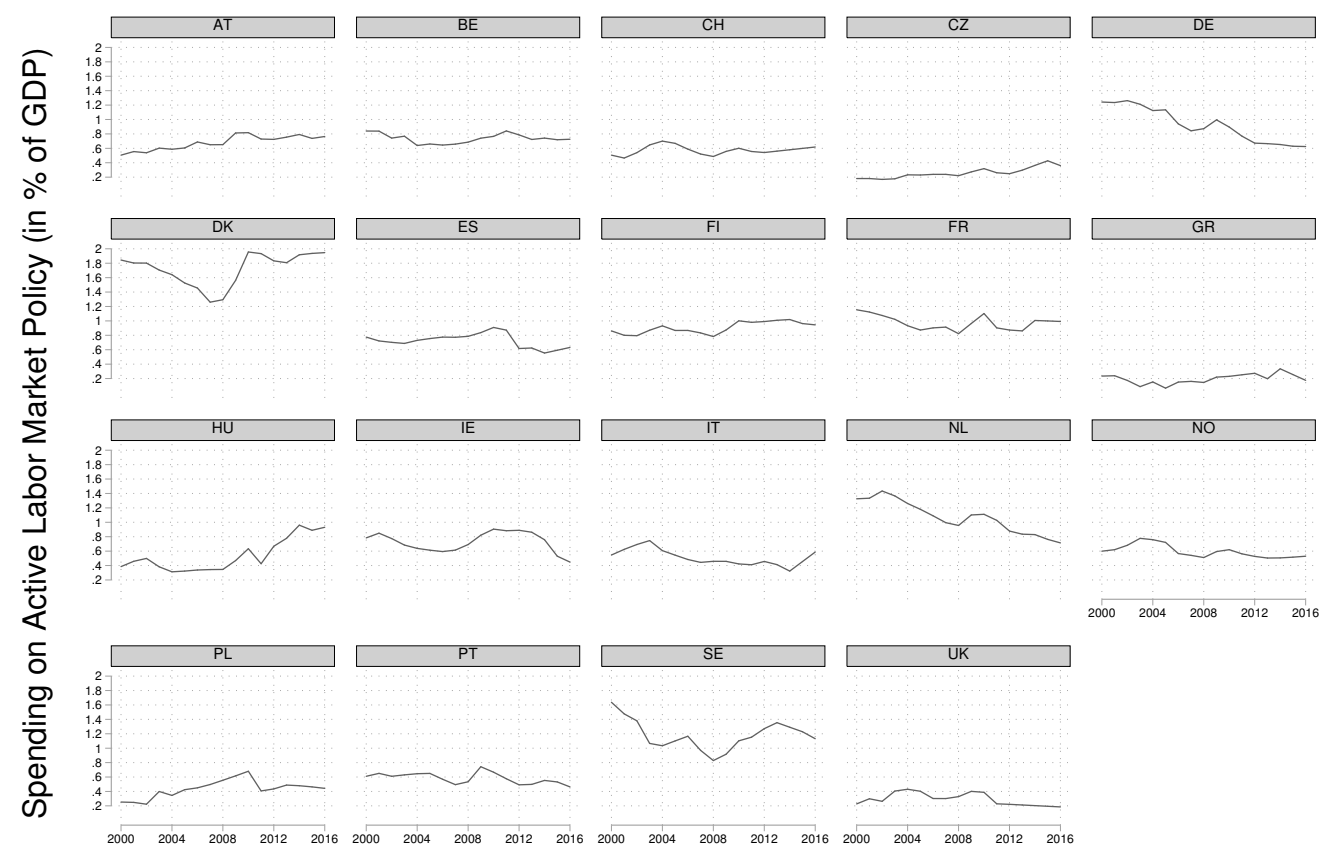

Figure SI2.7: Spending on active labor market policy in \% of GDP, by country 2000-2016 (Source: Armingeon et al. 2018)

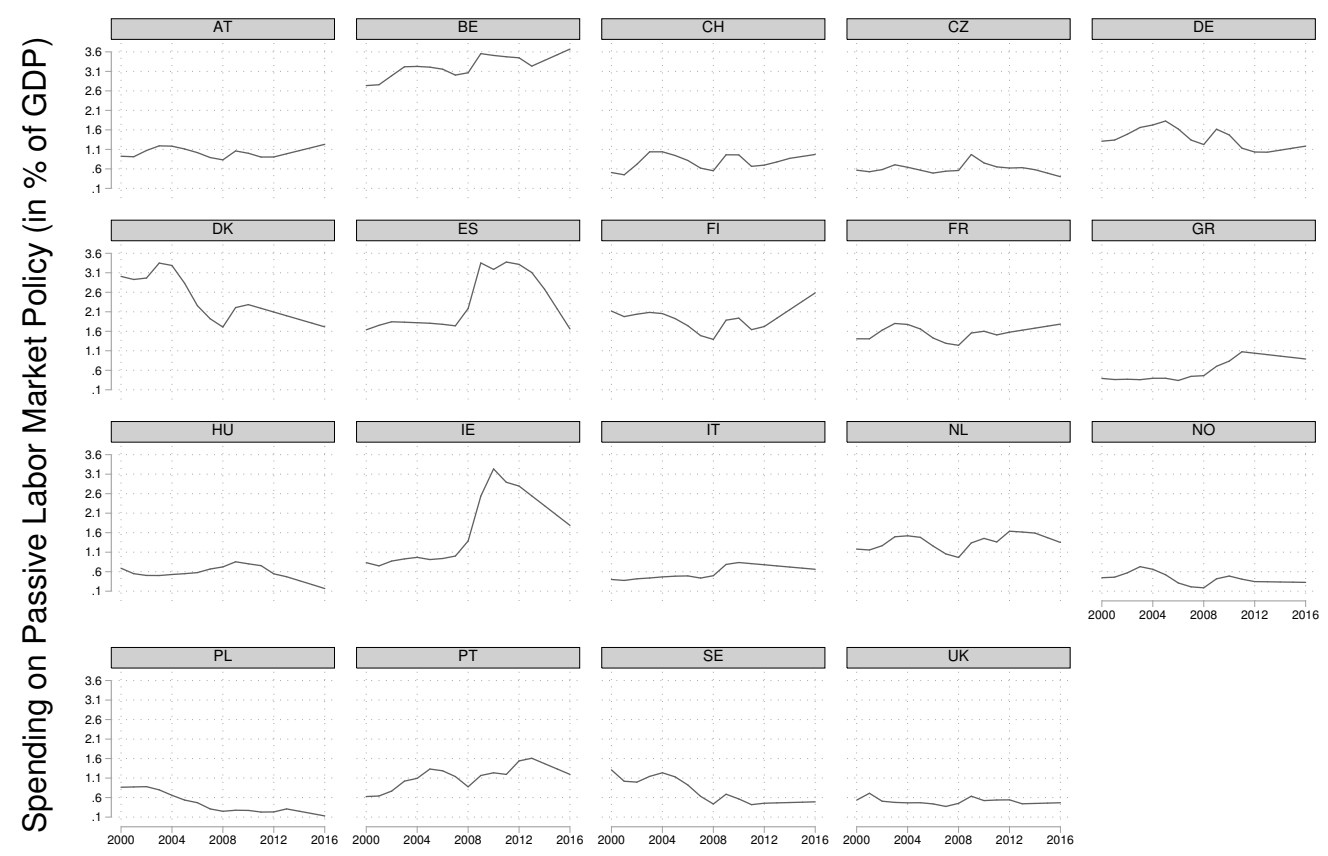

Figure SI2.8: Spending on passive labor market policy in \% of GDP, by country 2000-2016 (Source: Armingeon et al. 2018) 